\title{
Institutions Rule: The Primacy of Institutions over Integration and Geography in Economic Development
}

Dani Rodrik, Arvind Subramanian and

Francesco Trebbi 


\title{
IMF Working Paper
}

\begin{abstract}
African Department
Institutions Rule: The Primacy of Institutions over Integration and Geography in Economic Development
\end{abstract}

\author{
Prepared by Dani Rodrik, Arvind Subramanian and Francesco Trebbi ${ }^{1}$
}

November 2002

\begin{abstract}
The views expressed in this Working Paper are those of the author(s) and do not necessarily represent those of the IMF or IMF policy. Working Papers describe research in progress by the author(s) and are published to elicit comments and to further debate.
\end{abstract}

We estimate the respective contributions of institutions, geography, and trade in determining cross-country income levels using recently developed instruments for institutions and trade. Our results indicate that the quality of institutions "trumps" everything else. Controlling for institutions, geography have at best weak direct effects on incomes, although it has a strong indirect effect through institutions. Similarly, controlling for institutions, trade has a negative, albeit, insignificant direct effect on income, although trade too has a positive effect on institutional quality. We relate our results to recent literature, and where differences exist, trace their origins to choices on samples, specification, and instrumentation.

JEL Classification Numbers:F15, O11, P16, P51

Keywords: Institutions, integration, geography, development.

Authors'E-Mail Addresses: dani_rodrik@harvard.edu; asubramanian@imf.org; trebbi@fas.harvard.edu

\footnotetext{
${ }^{1}$ Dani Rodrik and Francesco Trebbi are from Harvard University and Arvind Subramanian is from the International Monetary Fund. The views expressed in this paper are the authors'own and not those of the institutions with which they are affiliated. We thank Chad Jones, James Robinson, Will Masters, and participants at the Harvard-MIT development seminar and the Harvard econometrics workshop for their comments; Daron Acemoglu for helpful conversation; and Aart Kraay for providing us with his data. Helen Hwang provided excellent secretarial assistance. Dani Rodrik gratefully acknowledges support from the Carnegie Corporation of New York.
} 


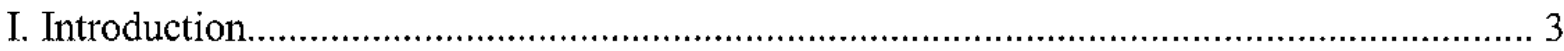

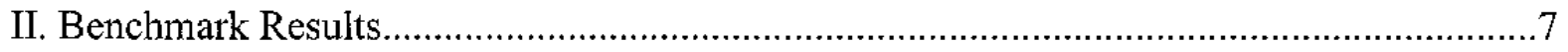

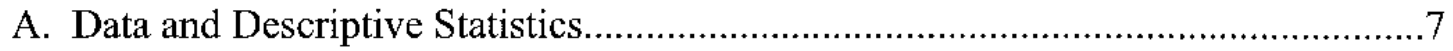

B. OLS and IV Results in the Core Specifications................................................

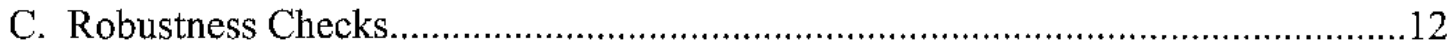

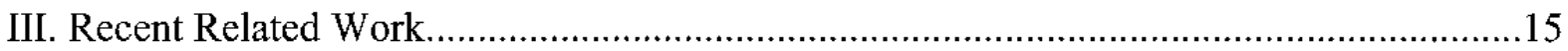

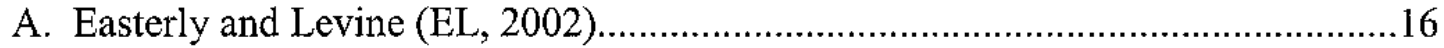

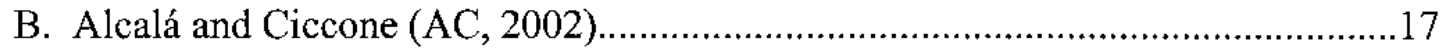

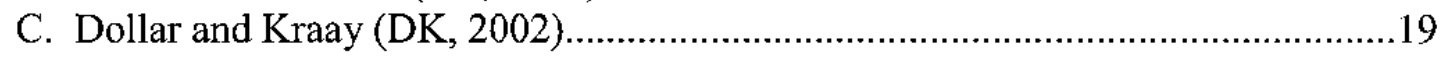

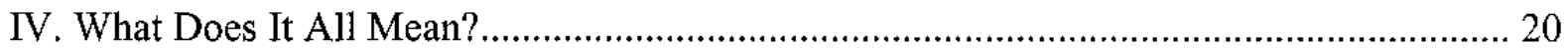

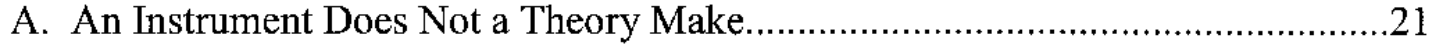

B. The Primacy of Institutional Quality Does Not Imply Policy Ineffectiveness.....22

C. The Hard Work is Still Ahead........................................................................23

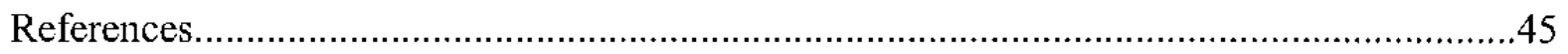

Figures

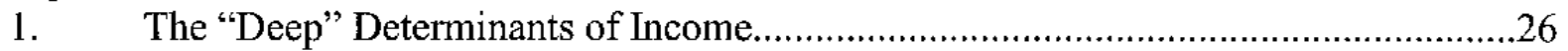

2. Simple Correlation Between Income and Its Determinants...................................27

3. Conditional Correlations Between Income and Its Determinants............................28

4. "Real Openness," Openness, and Income..........................................................29

5. Distribution of Incomes for Colonized and Noncolonized Countries.......................30

Tables

1. Descriptive Statistics: Panel A: Mean and Standard Deviation of Key Variables....31

Descriptive Statistics: Panel B: Pairwise Correlations............................................ 32

2. Determinants of Development: Core Specifications............................................33

3. Determinants of Development: Channels of Influence.........................................35

4. Determinants of Development: Robustness to "Influential" Observations, Neoeuropes, Legal Systems, Origin of Colonizer, and Religion.............................36

5. Determinants of Development: Robustness to Alternative Measures of

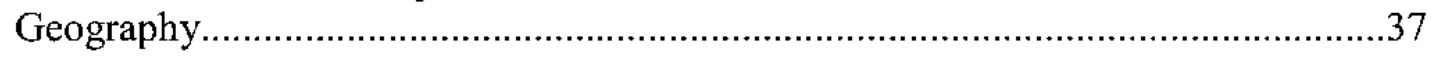

6. Determinants of Development: Robustness to Alternative Measures of, and

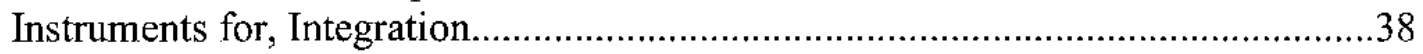

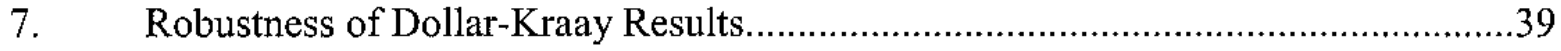

Appendices

I. The Inappropriateness of "Real Openness"................................................. 40

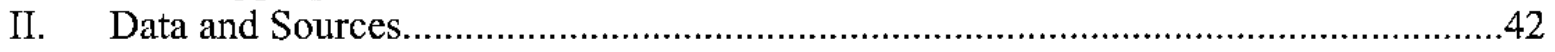


Commerce and manufactures can seldom flourish long in any state which does not enjoy a regular administration of justice, in which the people do not feel themselves secure in the possession of their property, in which the faith of contracts is not supported by law, and in which the authority of the state is not supposed to be regularly employed in enforcing the payment of debts from all those who are able to pay. Commerce and manufactures, in short, can seldom flourish in any state in which there is not a certain degree of confidence in the justice of government.

-- Adam Smith, The Wealth of Nations

\section{INTRODUCTION}

Average income levels in the world's richest and poorest nations differ by a factor of more than 100. Sierra Leone, the poorest economy for which we have national income statistics, has a per capita GDP of $\$ 490$, compared with Luxembourg's $\$ 50,061 .^{2}$ What accounts for these differences, and what (if anything) can we do to reduce them? It is hard to think of any question in economics that is of greater intellectual significance, or of greater relevance to the vast majority of the word's population.

In the voluminous literature on this subject, three strands of thoughts stand out. First, there is a long and distinguished line of theorizing that places geography at the center of the story. Geography is a key determinant of climate, endowment of natural resources, disease burden, transport costs, and diffusion of knowledge and technology from more advanced areas. It exerts therefore a strong influence on agricultural productivity and the quality of human resources. Recent writings by Jared Diamond and Jeffrey Sachs are among the more notable works in this tradition (see Diamond, 1997; Gallup, Sachs, and Mellinger, 1998; and Sachs, 2001).

A second camp emphasizes the role of international trade as a driver of productivity change. We call this the integration view, as it gives market integration, and impediments thereof, a starring role in fostering economic convergence between rich and poor regions of the world. Notable recent research in this camp includes Frankel and Romer (FR,1999) and the pregeography work of Sachs (Sachs and Warner 1995).

Finally, a third group of explanations centers on institutions, and, in particular, the role of property rights and the rule of law. In this view, what matters are the rules of the game in a society and their conduciveness to desirable economic behavior. This view is associated most strongly with Douglass North (1990). It has received careful econometric treatment recently in Hall and Jones (1999), who focus on what they call "social infrastructure," and in

\footnotetext{
${ }^{2}$ These are figures for 2000 , and they are expressed in current "international" dollars, adjusted for PPP differences. The source is the World Development Indicators CD-Rom of the World Bank.
} 
Acemoglu, Johnson, and Robinson (AJR, 2001), who focus on the expropriation risk that current and potential investors face.

Growth theory has traditionally focused on physical and human capital accumulation, and, in its endogenous growth variant, on technological change. But accumulation and technological change are at best proximate causes of economic growth. No sooner have we ascertained the impact of these two on growth - and with some luck their respective roles also - that we want to ask: But why did some societies manage to accumulate and innovate more rapidly than others? The threefold classification offered above-geography, integration, and institutions - allows us to organize our thoughts on the "deeper" determinants of economic growth. These three are the factors that determine which societies will innovate and accumulate, and therefore develop, and which will not.

Since long-term economic development is a complex phenomenon, the idea that any one (or even all) of the above deep determinants can provide an adequate accounting of centuries of economic history is, on the face of it, preposterous. Historians and many social scientists prefer nuanced, layered explanations where these factors interact with human choices and many other not-so-simple twists and turns of fate. But economists like parsimony. We want to know how well these simple stories do, not only on their own or collectively, but more importantly, vis-à-vis each other. How much of the astounding variation in cross-national incomes around the world can geography, integration, and institutions explain? Do these factors operate additively, or do they interact? Are they all equally important? Does one of the explanations "trump" the other two?

The questions may be simple, but devising a reasonable empirical strategy for answering them is far from straightforward. This is not because we do not have good empirical proxies for each of these deep determinants. There are many reasonable measures of "geography," such as distance from the equator (our preferred measure), percentage land mass located in the tropics, or average temperature. The intensity of an economy's integration with the rest of the world can be measured by flows of trade or the height of trade barriers. The quality of institutions can be measured with a range of perceptions-based indicators of property rights and the rule of law. The difficulty lies instead in sorting out the complex web of causality that entangles these factors.

The extent to which an economy is integrated with the rest of the world and the quality of its institutions are both endogenous, shaped potentially not just by each other and by geography, but also by income levels. Problems of endogeneity and reverse causality plague any empirical researcher trying to make sense of the relationships among these causal factors. We illustrate this with the help of Figure 1, adapted from Rodrik (2003, forthcoming). The plethora of arrows in the figure, going in both directions at once in many cases, exemplifies the difficulty.

The task of demonstrating causality is perhaps easiest for the geographical determinists. Geography is as exogenous a determinant as an economist can ever hope to get, and the main burden here is to identify the main channel(s) through which geography influences economic 
performance. Geography may have a direct effect on incomes, through its effect on agricultural productivity and morbidity. This is shown with arrow (1) in Figure 1. It can also have an indirect effect through its impact on distance from markets and the extent of integration (arrow [2]) or its impact on the quality of domestic institutions (arrow [3]). With regard to the latter, economic historians have emphasized the disadvantageous consequences for institutional development of certain patterns of factor endowments, which engender extreme inequalities and enable the entrenchment of a small group of elites (e.g., Engerman and Sokoloff, 1994). A similar explanation, linking ample endowment of natural resources with stunted institutional development, also goes under the name of "resource curse."

Trade fundamentalists and institutionalists have a considerably more difficult job to do, since they have to demonstrate causality for their preferred determinant, as well as identify the effective channel(s) through which it works. For the former, the task consists of showing that arrows (4) and (5)-capturing the direct impact of integration on income and the indirect impact through institutions, respectively - are the relevant ones, while arrows (6) and (7)reverse feedbacks from incomes and institutions, respectively - are relatively insignificant. Reverse causality cannot be ruled out easily, since expanded trade and integration can be mainly the result of increased productivity in the economy and/or improved domestic institutions, rather than a cause thereof.

Institutionalists, meanwhile, have to worry about different kinds of reverse causality. They need to show that improvements in property rights, the rule of law and other aspects of the institutional environment are an independent determinant of incomes (arrow [8]), and are not simply the consequence of higher incomes (arrow [9]) or of greater integration (arrow [5]).

In econometric terms, what we need to sort all this out are good instruments for integration and institutions - sources of exogenous variation for the extent of integration and institutional quality, respectively, that are uncorrelated with other plausible (and excluded) determinants of income levels. Two recent papers help us make progress by providing plausible instruments. FR (1999) suggests that we can instrument for actual trade/GDP ratios by using trade/GDP shares constructed on the basis of a gravity equation for bilateral trade flows. The FR approach consists of first regressing bilateral trade flows (as a share of a country's GDP) on measures of country mass, distance between the trade partners, and a few other geographical variables, and then constructing a predicted aggregate trade share for each country on the basis of the coefficients estimated. This constructed trade share is then used as an instrument for actual trade shares in estimating the impact of trade on levels of income.

Acemoglu, Johnson, and Robinson (AJR, 2001) use mortality rates of colonial settlers as an instrument for institutional quality. They argue that settler mortality had an important effect on the type of institutions that were built in lands that were colonized by the main European powers. Where the colonizers encountered relatively few health hazards to European settlement, they erected solid institutions that protected property rights and established the rule of law. In other areas, their interests were limited to extracting as much resources as quickly as possible, and they showed little interest in building high-quality institutions. Under the added assumption that institutions change only gradually over time, AJR argue 
that settler mortality rates are therefore a good instrument for institutional quality. FR (1999) and AJR (2001) use their respective instruments to demonstrate strong causal effects from trade (in the case of FR) and institutions (in the case of AJR) to incomes. But neither paper embeds their estimation in the broader framework laid out above. More specifically, AJR control for geographical determinants, but do not check for the effects of integration. FR do not control for institutions.

Our approach in this paper consists of using the FR and AJR instruments simultaneously to estimate the structure shown in Figure 1. The idea is that these two instruments, having passed what might be called the AER (American Economic Review)-test, are our best hope at the moment of unraveling the tangle of cause-and-effect relationships involved. So we systematically estimate a series of regressions in which incomes are related to measures of geography, integration, and institutions, with the latter two instrumented using the FR and AJR instruments. These regressions allow us to answer the question: what is the independent contribution of these three sets of deep determinants to the cross-national variation in income levels? The first stage of these regressions provides us in turn with information about the causal links among the determinants.

This exercise yields some sharp and striking results. Most importantly, we find that the quality of institutions trumps everything else. Once institutions are controlled for, integration has no direct effect on incomes, while geography has at best weak direct effects. Trade often enters the income regression with the "wrong" (i.e., negative) sign, as do many of the geographical indicators. By contrast, our measure of property rights and the rule of law always enters with the correct sign, and is statistically significant, often with t-statistics that are very large.

On the links among determinants, we find that institutional quality has a positive and significant effect on integration. Importantly, integration also has a (positive) impact on institutional quality, suggesting that trade can have an indirect effect on incomes by improving institutional quality. Our results also tend to confirm the findings of Easterly and Levine (2002), namely that geography exerts a significant effect on the quality of institutions.

Our preferred specification "accounts" for about half of the variance in incomes across the sample, with institutional quality (instrumented by settler mortality) doing most of the work. Our estimates indicate that an increase in institutional quality of one standard deviation, corresponding roughly to the difference between measured institutional quality in Bolivia and South Korea, produces a 2 log-points rise in per-capita incomes, or a 6.4 -fold difference - which, not coincidentally, is also roughly the income difference between the two countries. In our preferred specification, trade and distance from the equator both exert a negative, but insignificant effect on incomes (see Table 2, panel B, column 6).

Much of our paper is devoted to checking the robustness of our central results. In particular, we estimate our model for three different samples: (a) the original 64-country sample used by AJR; (b) an 80-country sample which is the largest sample we can use while still retaining the AJR instrument; and (c) a 140-country sample that maximizes the number of countries at 
the cost of replacing the AJR instrument with two more widely available instruments (fractions of the population speaking English and Western European languages as the first language, from Hall and Jones, 1999). We also use a large number of alternative indicators of geography, integration, and institutions. In all cases, institutional quality emerges as the clear winner of the "horse race" among the three. Finally, we compare and contrast our results to those in some recent papers that have undertaken exercises of a similar sort. Where there are differences in results, we identify and discuss the source of the differences and explain why we believe our approach is superior on conceptual or empirical grounds.

The plan of the paper is as follows. Section II presents the benchmark results. Section III discusses related recent work and compares it to ours. Section IV provides a more in-depth interpretation of our results and lays out a research agenda.

\section{BENCHMARK RESULTS}

\section{A. Data and Descriptive Statistics}

Table 1 provides descriptive statistics for the key variables of interest. The first column covers the sample of 80 countries for which data on settler mortality have been compiled by $\mathrm{AJR}^{3}$ Given the demonstrated attractiveness of this variable as an instrument that can help illuminate causality, this will constitute our preferred sample. The second column contains summary statistics for a larger sample of 140 countries for which we have data on alternative instruments for institutions (fractions of the population speaking English and other European languages). Data for the FR instrument on trade, on which we will rely heavily, are also available for this larger sample.

GDP per capita on a PPP basis for 1995 will be our measure of economic performance. For both samples, there is substantial variation in GDP per capita: for the 80-country sample, mean GDP in 1995 is $\$ 3,020$, the standard deviation of log GDP is 1.05 , with the poorest country's (Congo, DRC ${ }^{4}$ ) GDP being $\$ 321$ and that of the richest (Singapore) $\$ 28,039$. For the larger sample, mean income is $\$ 4,452$, the standard deviation is 1.14 , with the richest country (Luxembourg) enjoying an income level of $\$ 34,698$.

The institutional quality measure that we use is due to Kaufmann, Kraay, and Zoido-Lobaton (2002). This is a composite indicator of a number of elements that capture the protection

\footnotetext{
${ }^{3}$ AJR actually compiled data on settler mortality for 81 countries, but data on per capita PPP GDP for 1995 are unavailable for Afghanistan.

${ }^{4}$ Throughout this paper Congo, DRC and Zaire (ZAR), will be used interchangeably to refer to the Democratic Republic of the Congo.
} 
afforded to property rights as well as the strength of the rule of law. ${ }^{5}$ This is a standardized measure that varies between -2.5 (weakest institutions) and 2.5 (strongest institutions). In our sample of 80 countries, the mean score is -0.25 , with Zaire (score of -2.09 ) having the weakest institutions and Singapore (score of 1.85) the strongest.

Integration, measured using the ratio of trade to GDP, also varies substantially in our sample. The average ratio is 51.5 percent, with the least "open" country (India) posting a ratio of 13 percent and the most "open" (Singapore) a ratio of 324 percent. Our preferred measure of geography is a country's distance from the equator (measured in degrees). The typical country is about 15.2 degrees away from the equator.

\section{B. OLS and IV Results in the Core Specifications}

Our paper represents an attempt to estimate the following equation:

$$
\log \mathrm{y}_{i}=\mu+\alpha I N S_{\mathrm{i}}+\beta I N T_{\mathrm{i}}+\gamma G E O_{\mathrm{i}}+\varepsilon_{i}
$$

where $\mathrm{y}_{\mathrm{i}}$ is income per capita in country $\mathrm{i}, I N S_{\mathrm{i}}, I N T_{\mathrm{i}}$, and $G E O_{\mathrm{i}}$ are respectively measures for institutions, integration, and geography, and $\varepsilon_{\mathrm{i}}$ is the random error term. Throughout the paper, we will be interested in the size, sign, and significance of the three coefficients $\alpha, \beta$, and $\gamma$. We will use standardized measures of $I N S_{\mathrm{i}}, I N T_{\mathrm{i}}$, and $G E O_{\mathrm{i}}$ in our core regressions, so that the estimated coefficients can be directly compared.

Before we discuss the benchmark results, it is useful to look at the simple, bivariate relationships between income and each of the "deep determinants." Figure 2 shows these scatter plots, with the three panels on the left hand side corresponding to the sample of 80 countries and the three panels on the right to the larger sample of 140 countries. All the plots show a clear and unambiguously positive relationship between income and its possible determinants. Thus, any or all of them have the potential to explain levels of income. This positive relationship is confirmed by the simple OLS regression of equation (1) reported in Panel A of Table 2. The signs of institution, openness, and geography are as expected and statistically significant or close to being so. Countries with stronger institutions, more open economies, and more distant from the equator are likely to have higher levels of income.

To get a sense of the magnitude of the potential impacts, we can compare two countries, say Nigeria and Mauritius, both in Africa. If the OLS relationship is indeed causal, the coefficients in column (6) of Panel A in Table 2 would suggest that Mauritius's per capita

\footnotetext{
${ }^{5}$ AJR use an index of protection against expropriation compiled by Political Risk Services. The advantage of the rule of law measure used in this paper is that it is available for a larger sample of countries, and in principle captures more elements that go toward determining institutional quality. In any case, measures of institutional quality are highly correlated: in our 80-country sample, the two measures have a simple correlation of 0.78 .
} 
GDP should be 5.2 times that of Nigeria, of which 21 percent would be due to better institutions, 65 percent due to greater openness, and 14 percent due to better location. In practice, Mauritius's income $(\$ 11,400)$ is 14.8 times that of Nigeria $(\$ 770)$.

Of course, for a number of reasons described extensively in the literature-reverse causality, omitted variables bias, and measurement error - the above relationship cannot be interpreted as causal or accurate. To address these problems, we employ a two-stage least squares estimation procedure. The identification strategy is to use the AJR settler mortality measure as an instrument for institutions and the FR measure of constructed trade shares as an instrument for integration. In the first-stage regressions, $I N S_{\mathrm{i}}$ and $I N T_{\mathrm{i}}$ are regressed on all the exogenous variables. Thus:

$$
\begin{aligned}
& I N S_{i}=\lambda+\delta S M_{i}+\phi \operatorname{CONST}_{i}+\psi G E O_{i}+\varepsilon_{\mathrm{INS} i} \\
& I N T_{i}=\theta+\sigma \operatorname{CONST}_{i}+\tau S M_{i}+\omega G E O_{i}+\varepsilon_{I N T i}
\end{aligned}
$$

where $S M_{i}$ refers to settler mortality and $C O N S T_{i}$ to the $F R$ instrument for trade/GDP. The exclusion restrictions are that $S M_{i}$ and $C O N S T_{i}$ do not appear in equation (1).

Equations (1)-(3) constitutes our core specification. This specification represents, we believe, the most natural framework for estimating the respective impacts of our three deep determinants. It is general, yet simple, and treats each of the three deep determinants symmetrically, giving them all an equal chance. Our proxies for institutions, integration, and geography are the ones that the advocates of each approach have used. Our instruments for institutions and integration are sensible, and have already been demonstrated to "work" in the sense of producing strong second-stage results (albeit in estimations not embedded in our broader framework).

Panel B of Table 2 reports the two-stage least squares estimates of the three coefficients of interest. The estimation is done for three samples of countries: (i) for the sample of 64 countries analyzed by AJR; (ii) for an extended sample of 80 countries for which AJR had compiled data on settler mortality; and (iii) for a larger sample of 140 countries that includes those that were not colonized. In AJR, the quality of institutions was measured by an index of protection against expropriation. We use a rule of law index because it is available for a larger sample. The IV estimates of the coefficient on institutions in the first three columns of Panel B are very similar to those in AJR, confirming that these two indexes are capturing broadly similar aspects of institutions, and allowing us to use the larger sample for which data on settler mortality are available.

Columns (4)-(6) report our estimates for the extended AJR sample (which as we shall explain below will be our preferred sample in this paper). Columns (5) and (6) confirm the importance of institutions in explaining the cross-country variation in development. Once the institutional variable is added, geography and openness do not have any additional power in explaining development. Institutions trump geography and openness. In our preferred 
specification (column (6)), not only are institutions significant, their impact is large, and the estimated coefficients on geography and openness have the "wrong" sign! The coefficient on institutions in the IV estimation is nearly three times as large as in the corresponding OLS estimation ( 2 versus 0.7 ), suggesting that the attenuation bias from measurement error in the institution variables swamps the reverse causality bias that would tend to make the OLS estimates greater than the IV estimates.

The results are similar for the larger sample of countries (Panel B, columns (6) to (9)). In this sample, we follow Hall and Jones (1998) and Dollar and Kraay (2002) in using the following two variables as instruments for institutional quality (in lieu of settler mortality):

ENGFRAC, fraction of the population speaking English, and EURFRAC, fraction of the population speaking other European languages. Once again, institutions trump geography and openness, although the size of the estimated coefficient is smaller than that for the smaller sample. Figure 3 plots the conditional relationship between income and each of the three determinants for the 80-country (left panels) and 140-country (right panels) samples. In contrast to Figure 2, which showed a positive partial relationship between income and all its determinants, Figure 3 shows that only institutions have a significant and positive effect on income once the endogenous determinants are instrumented.

The first-stage regressions (reported in Panel C) are also interesting. In our preferred specification, settler mortality has a significant effect on integration: the coefficient is correctly signed and significant at the 1 percent level. This result holds for the range of specifications that we estimate as part of the robustness checks reported below. The geography variable has a significant impact in determining the quality of institutions as does integration, although its coefficient is significant only at the 5 percent level.

While all three samples provide qualitatively similar results, our preferred sample will be the 80-country sample: obviously this sample Pareto-dominates the 64-country sample. We also prefer this sample to the 140-country sample because settler mortality appears to be a superior instrument to those used in the 140-country sample (ENGFRAC and EURFRAC). Panel B shows that the instruments for the IV regressions in the 140-country sample fail to pass the over-identification tests despite the well-known problems of these tests having low power. Indeed, this turns out to be true not just for the core specifications in Table 2, but for many of the robustness tests that we discuss below. This raises questions about the results in Hall and Jones (1998) and in Dollar and Kraay (2002), which are based on the use of ENGFRAC and EURFRAC as instruments for institutions. Thus, while it is reassuring that the main result regarding the primacy of institutions also holds in the larger sample, we will focus mainly on the 80-country sample in the rest of the paper (referring to results for the larger sample in passing). ${ }^{6}$ We shall examine the robustness of our main results in the next section.

${ }^{6}$ The larger sample guards against a possible selection bias that could arise in the 80-country sample that consists entirely of former colonies. If, for example, countries that were colonized were not selected randomly but because of certain characteristics that are 
Columns (10) and (11) show the inter-relationships between integration and institutions in the 80-country sample. We regress trade and institutional quality separately on geography and on each other (instrumenting the endogenous variables in the manner discussed previously). The IV regressions show that each of these exerts a positive impact on the other, with the larger quantitative impact being that of institutional quality on trade. A unit increase in institutional quality increases the trade share by 0.77 units, while a unit increase in trade increases institutional quality by 0.23 units. Hence these estimates suggest that integration can have an indirect effect on incomes via its effect on institutional quality.

Taking these indirect effects into account, we can calculate the total impacts on incomes of these two determinants by combining the estimated parameters. Our estimates of $\alpha$ and $\beta$ (the direct effects) in our preferred sample and specification are 2.00 and -0.30 , respectively (column 6). We can solve the system of equations implied by the additional results in columns (10) and (11) to calculate the total effects on log incomes of "shocks" to the error terms in the institutions and trade equations.

The results are as follows. If we consider the point estimates in equation (6) as our best estimate of the various effects, a unit (positive) shock to the institutional quality equation ultimately produces an increase in log incomes of 2.15; a unit (positive) shock to the trade equation ultimately produces an increase in log incomes of 0.2 . This is a ten-fold difference. Alternatively, we could consider the direct impact of trade on income to be nil, since the relevant estimate $(\beta)$ is statistically indistinguishable from zero. Under this assumption, a unit shock to the institutional quality equation ultimately produces an increase in log incomes of 2 , while a unit shock to the trade equation produces an increase in log incomes of 0.46 . Instituions trump integration by a factor of 4.4 .

The much greater impact of institutions is the consequence of three factors: (i) the estimated direct effect of institutions on incomes is positive and large; (ii) the estimated direct effect of trade on incomes is negative (but statistically insignificant); and (iii) the estimated effect of trade on institutions is positive, but small.

The proximate determinants of economic growth are accumulation (physical and human) and productivity change. How do the deep determinants influence these channels? To answer this question, we regressed income per worker and its three proximate determinants, physical capital per worker, human capital per worker, and total factor productivity (strictly speaking a labor-augmenting technological progress parameter) on the deep determinants. Data for the left hand side variables for these regressions (i.e. income, physical, and human capital per worker, and factor productivity are taken from Hall and Jones (1998). These results are

correlated with the right hand side variables, the coefficient estimates in the 80-country sample could be biased. 
reported in Table 3 for both the 80-country sample (columns 1-4) and the 140-country sample (columns 5-9). ${ }^{7}$ Three features stand out.

First, the regression for income per worker is very similar to the regressions for per capita income reported in Table 2 , with institutions exerting a positive and significant effect on income, while integration and geography remain insignificant. Second, and interestingly, the same pattern holds broadly for the accumulation and productivity regressions; that is, institutions are an important determinant of both accumulation and productivity, while integration and geography are not influential in determining either accumulation or productivity. ${ }^{8}$ Finally, it is interesting to note that institutions have a quantitatively larger impact on physical accumulation than on human capital accumulation or productivity; for example, in the 80-country sample the coefficient on physical capital accumulation is about six times greater than on human capital accumulation and about 3.2 times greater than on productivity. One possible interpretation is that these results emphasize the particularly important role that institutions play in preventing expropriability of property which serves as a powerful incentive to invest and accumulate physical capital.

\section{Robustness Checks}

Tables 4,5 , and 6 present our robustness checks. In Table 4 we test whether our results are driven by certain influential observations or by the 4 neo-European countries in our sample (Australia, Canada, New Zealand, and Australia), which are arguably different from the rest of the countries included. We also check to see whether the inclusion of regional dummies affects the results.

In columns $(1)^{*}$ and $(1)^{* *}$ of Table 4 we use the Belsey-Kuh-Welsch (1980) test to check whether individual observations exert unusual leverage on the coefficient estimates, discarding those which do so. In the specification without regional dummies $\left((1)^{*}\right)$, two observations-Ethiopia and Singapore-are influential. Once these are dropped, the coefficient estimate for institutions not only remains statistically unaffected, but increases in magnitude. In the equation with regional dummies, the test requires the observation for Ethiopia to be omitted, and the revised specification yields results very similar to the baseline specification, with the coefficient estimate on institutions remaining strong and significant. The inclusion of regional dummies for Latin America, Sub-Saharan Africa, and Asia tends to lower somewhat the estimated coefficient on institutions, but its significance level remains

\footnotetext{
${ }^{7}$ Sample sizes are reduced because of the unavailability of the dependent variables for all countries.

${ }^{8}$ In the larger sample, integration has a negative and significant effect on income and accumulation but this result is not robust to the inclusion of additional variables such as land and area.
} 
unaffected. Note also that none of the regional dummies enters significantly, which is reassuring regarding the soundness of our parsimonious specification.

The tests for influential observations suggest that there is no statistical basis for discarding neo-European countries. Nevertheless to confirm that these countries are not driving the results, we re-estimated the baseline specification without these observations. As the column labeled $(1)^{* * *}$ confirms, the coefficient estimates are unaffected; indeed, once again the size of the coefficient on institutions rises substantially, suggesting the greater importance of institutions for the non-neo-European colonized countries. The remaining columns confirm that our results are robust also for the larger sample of countries.

We then check whether our results are robust to the inclusion of dummies for legal origin (column (3)), for the identity of colonizer (column (4)), and religion (column (5)). La Porta et. al. (1999) argue that the type of legal system historically adopted in a country or imported through colonization has an important bearing on the development of institutions and hence on income levels. Similar claims are made on behalf of the other variables. In all cases, while these variables themselves tend to be individually and in some cases jointly significant, their inclusion does not affect the core results about the importance of institutions and the lack of any direct impact of geography and integration on incomes. Indeed, controlling for these other variables, the coefficient of the institutions variable increases: for example, in the 80 -country sample, this coefficient increases from 2 in the baseline to 2.38 when the legal origin dummies are included. ${ }^{9}$

In Table 5 we check whether our particular choice of measure for geography (distance from the equator) influences our results. We successively substitute in our baseline specification a number of measures of geography used in the literature. These measures include percent of a country's land area in the tropics (TROPICS), access to the sea (ACCESS), number of frost days per month in winter (FROSTDAYS), the area covered by frost (FROSTAREA), whether a country is an oil exporter (OIL), prevalence of malaria (MALFAL94), and mean temperature (MEAN TEMPERATURE). The variables FROSTDAYS and FROSTAREA are taken from Masters and McMillan (2001), who argue that the key disadvantage faced by tropical countries is the absence of winter frost. (Frost kills pests, pathogens and parasites, thereby improving human health and agricultural productivity.) We find that none of these variables, with the exception of the oil dummy, is statistically significant in determining incomes. Equally importantly, they do not change qualitatively our estimates of the

\footnotetext{
${ }^{9}$ We do not report the results for the larger sample but they are very similar. For the 80-country sample, interesting results are obtained for some of the individual legal origin and other variables. For example, as in AJR (2001), the French legal origin dummy has a positive total effect on incomes; the total impact of having been colonized by the UK is negative and statistically significant even though former UK-colonies have better quality of institutions on average. As for religion, well, suffice it to say that Weber is not vindicated!
} 
institution variable, which remains significant, nor of the integration variable, which remains insignificant and "wrongly" signed. ${ }^{10}$

In columns (9), (10), and (11), we test whether geography has an impact through a combination of effects captured by the different geography variables. In equation (9), we control jointly for distance from equator and the malaria variable. The $p$-value for the joint significance of the two geographical variables is well below one percent. The same happens when this specification is expanded to include the number of frost days per month in winter (column (10)). The F-test for joint significance of the geography pool rejects the null of no significant effect in the second stage. ${ }^{11}$

However, when we slightly enlarge the pool to include the other two geography variables, tropical area and mean temperature, all the individual effects become insignificant as does the joint significance of all the geography variables (the corresponding p-value is 15 percent). As for individual effects, in columns (9) and (10), malaria seems to be important in explaining income differences and enters significantly at the 5 or 10 percent level ${ }^{12}$ But its coefficient is about 4 times smaller than that for institutions. Finally, we experimented with a series of specifications (not reported) that involved interacting the different geography variables with each other as well as introducing different functional forms (for example, exponential) for them. These did not provide evidence in favor of significant direct effects of geography on income. Overall, we conclude that there seems to be some, albeit modest, support for the direct impact of geography on income. The first stage regressions, however, point clearly in favor of an important indirect role of geography via institutions.

In Table 6, we check whether our results are sensitive to our omission of market size variables, or our measures of and instruments for openness. Frankel and Romer (1999) argue that smaller countries tend to trade more, and that one should therefore control for country size when looking for the effect of trade on incomes. The column labeled (1) in Table 6 includes two measures of country size-area and population. These variables do not have additional explanatory power in the income equation, which is different from the results in Frankel and Romer (1999). The size and significance of the coefficient on institutions are unaffected. The coefficient on openness becomes positive, but is highly insignificant.

${ }^{10}$ In six of the eight regressions (excluding the one with the oil dummy), the geography variable is a significant determinant of institutions in the first stage regressions.

${ }^{11}$ In the corresponding first stage regressions, settler mortality continues to be important even after controlling for malaria prevalence, with F-statistics above 12 in both equations (9) and (10).

${ }^{12}$ We note, however, that it is difficult to treat malaria incidence as an exogenous variable; as the successful eradication of malaria from Mauritius, Singapore, and southern Italy demonstrates, it is obviously influenced by institutions. 
Column (3) replicates this exercise for the larger sample. The coefficient on institutions does not change qualitatively (but the standard error is sharply reduced as is the coefficient estimates), while the coefficient on openness is still negatively signed.

Alcala and Ciccone (AC, 2002) argue that "real openness", measured as the ratio of trade to PPP GDP is a better measure of integration than the simple ratio of trade to GDP that FR and we favor. In the next section, we examine in greater detail the merits of their argument, but here we test empirically whether this alternative measure affects our results. Column (5) presents the results. Once again, this integration measure is wrongly signed and insignificant, while the coefficient on institutions increases in size and remains significant, albeit at the 5 percent level.

Columns (2), (4) and (6) replicate the three robustness checks described above but with an instrument for openness that is slightly different from that in Frankel and Romer (1999). To obtain their instruments, FR estimated a gravity equation with the dependent variable defined as trade to PPP GDP. Strictly speaking therefore, theirs was an appropriate instrument for AC's "real openness." We re-estimated the gravity equation on the original FR sample of 63 countries, with trade to GDP as the dependent variable. We then used the coefficients from this gravity equation to construct the instrument for openness for all the 140 countries in our larger sample. The results in columns (2), (4), and (6) are very similar to those using the original FR instruments. The choice of instruments thus does not affect our main results.

Finally, in column (7) we substitute a "policy" measure for the trade variable. For reasons explained later, we believe that it is not appropriate to use policy variables in level regressions. We nevertheless sought to test the robustness of our results to one of the mostwidely used measures in the trade and growth literature due to Sachs and Warner (1995), which has been endorsed recently by Krueger and Berg (2002). ${ }^{13}$ The results show that the institutional variable remains significant at the 5 percent level and the Sachs-Warner measure is itself wrongly signed like the other openness measures.

\section{RECENT RELATED WORK}

The present paper represents in our view the most systematic attempt to date to estimate the relationship between integration, institutions, and geography, on the one hand, and income, on the other. Recently a few other papers have carried out somewhat similar analyses and deserve discussion. The three papers we focus on are Easterly and Levine (EL, 2002), Alcalá and Ciccone (AC, 2002), and Dollar and Kraay (DK, 2002). ${ }^{14}$ Our reading of EL is that it is

${ }^{13}$ The shortcomings of the Sachs-Warner index as a measure of trade policy are discussed at length in Rodriguez and Rodrik (2001).

${ }^{14}$ See also Frankel and Rose (2002), which builds on FR. This paper is critiqued by Rodrik (2000), who argues that the results are not robust to the exclusion of two highly influential 
largely consistent with our results, although, as we shall discuss, the interpretations are somewhat different. The results reported in $\mathrm{AC}$ and $\mathrm{DK}$ are at variance with ours to a much greater extent, but in different ways. AC claim trade and institutions are both significant, while DK claim that the instrumented income-level regressions exhibit too much collinearity between the two determinants for their respective contributions to be ascertained. We will identify in this section the specific departures from the framework we laid out in this paper that account for the divergent results that these authors have found. In particular, we will show that the differences derive from choices on samples, specification, or instruments that we think are arbitrary. But the point of identifying the origin of the difference is to allow the reader to make up his/her own mind.

\section{A. Easterly and Levine (EL, 2002)}

The EL approach is in some ways very similar to that in this paper. EL estimate regressions of the levels of income on various measures of endowments, institutions, and "policies." They find that institutions exert an important effect on development, while endowments do not, other than through their effect on institutions. Policies also do not exert any independent effect on development. The main differences between our paper and EL are the following.

First, we use a larger sample of countries (80 and 140) to run the "horse" race between the three possible determinants. The EL sample is restricted to 72 countries. Second, EL do not test in any detail whether integration has an effect on development. For them, integration or open trade policy is part of a wider set of government policies that can affect development. Testing for the effect of policies in level regressions is, however, problematic as discussed in greater detail below. Policies pursued over a short time span, say 30-40 years, are like a flow variable, whereas development, the result of a much longer cumulative historical process, is more akin to a stock variable. Thus, level regressions that use policies as regressors conflate stocks and flows. Testing for integration is less vulnerable to this critique because of the instrumentation strategy for measuring integration, which relies essentially on geography variables that are time-invariant.

Finally, we also differ from EL in the interpretation of the results. EL tend to a deterministic view of institutions, interpreting settler mortality, which is essentially an econometric instrument for capturing the exogenous source of variation in institutions, as a causal geographical determinant of institutions. As we show below, this would render institutions more immutable than they have actually proven to be.

variables (Hong Kong and Singapore) and the inclusion of institutional quality and geography as additional regressors. 


\section{B. Alcalá and Ciccone (AC, 2002)}

The key innovation in AC is the advocacy and justification of what they call "real openness" as a better measure for integration. ey first note that the FR result on the significance of trade in determining income is not robust to the inclusion of distance from equator in the income equation. ${ }^{15}$ They then argue that part of the problem is that the conventional measure of openness that FR and others use--nominal trade divided by nominal GDP-can yield an estimate of trade on productivity that is biased downwards. The logic is as follows. Suppose that an increase in trade raises productivity, but that it does so predominantly in the tradables sector. Unless non-tradables are inferior in demand, this will raise the relative price of nontradables. This will in turn tend to depress the ratio of trade to nominal GDP. The result is that the initial increase in the openness ratio will be attenuated. AC therefore prefer to use what they call "real openness," nominal trade divided by PPP GDP.

AC find a relationship between "real openness" and income within their empirical framework that they claim is more robust than when the conventional measure of openness is used. This seems to be the case even when institutional quality is entered, which shows up significantly in their regressions as well. Since we were unable to obtain their data set, we could not replicate their results exactly. However, as columns 5 and 6 of Table 6 illustrate, the use of "real openness" within our empirical specification does not alter the central results of our paper, namely the importance of institutions and the insignificance of openness.

Moreover, the $\mathrm{AC}$ argument strikes us as being misleading. To see why, first note that the use of "real openness" can yield in fact an opposite, and potentially more severe, bias. What $\mathrm{AC}$ do not recognize is that the actual null hypothesis that is tested is that trade does not cause productivity. Under that null, AC's real openness measure generates a positive correlation between income and openness that is entirely spurious. In effect, the AC adjustment has the consequence that any and all increases in the productivity of tradables, regardless of source, can produce a rise in their measure of openness. Any increase in tradables productivity, whether driven by trade or not, will raise nontradables prices at home and the price level of an economy relative to others. "Adjusting" for this by using PPP GDP as the denominator drives up measured openness. The conventional measure of openness does not suffer from that shortcoming, and hence is preferable. We explain and illustrate this point in Appendix I using a simple model. We show, under fairly innocuous assumptions, that conventional openness will yield less biased results than real openness when productivity in the tradables sector is driven by non-trade factors.

${ }^{15}$ The estimated coefficient (t-statistic) on openness in the second stage FR equation drops from 1.97 (1.99) to 0.34 (0.41) when distance is added. See Rodriguez and Rodrik (2001, Table 7) and Irwin and Trevio (2000). Note that FR $(1999,389)$ reported in their robustness checks that their results were unaffected by the inclusion of distance from equator. However, this statement seems to have been erroneous, as the "distance" variable used in the FR regression was apparently latitude rather than the appropriate transformation abs(latitude)/90. 
The empirical counterpart of this point is that the AC measure of openness is much more strongly correlated with income levels than the conventional measure of openness. Note that real openness (Ropen) and openness (Open) are linked by the identity log Ropen $=\log$ Open $+\log \mathbf{P}$, where $\mathbf{P}$ is a country's price level. We know from the Balassa-Samuelson argument that $\mathrm{P}$ has a close relationship to a country's income/productivity level. This is confirmed by the scatter plot in Figure (4), which shows the difference between these two measures (i.e., log openness - log "real openness") plotted against income. The correlation is extremely high $(\rho=0.75)$. Under the null hypothesis that trade does not cause productivity, this association is spurious. And even under the null that trade does cause productivity, the observed association would be biased upwards unless the only cause of productivity changes is trade (see Appendix I). ${ }^{16}$

Our second point relates to the choice between real openness and openness on econometric grounds. Recall that the authors' original argument on behalf of Ropen is based on the idea that there is reverse causality from productivity to Open, via the price level. If the FrankelRomer constructed trade share is a valid instrument, in the sense of being uncorrelated with productivity through any channel other than trade, any type of reverse causality-positive or negative-is already taken care of. The reverse causality that $\mathrm{AC}$ worry about should be handled by the instrument as well! For the authors' argument to be valid, instrumentation should fail when Open is used, but work when Ropen is used (even though the same instruments are used in both cases). The authors do not provide any justification for this, and it is unclear to us that any justification could be produced.

Moreover, it is possible that the AC strategy does exactly the reverse and that it weakens the instrument. As we mentioned above, we were unable to obtain AC's data and could note replicate their results exactly. But in our attempted replications of their baseline specification, we repeatedly found that the first-stage F statistics were lower, sometimes substantially so, when real openness was used in lieu of openness. In fact, the F-statistic was typically below 10 when real openness was used (and always above 10 when openness was used). ${ }^{17}$

\footnotetext{
${ }^{16}$ Indeed the $\mathrm{AC}$ argument that the true relationship between trade and productivity can be ascertained only by holding the price level constant suggests estimating a more general framework of the kind: $\log y=\alpha+\beta_{l} \log$ Open $+\beta_{2} \log P+v$. When we do so, using an instrument set close to that in $\mathrm{AC}$, we find that the coefficient on openness is negative and insignificant, and that on the price level positive and highly significant. The comparable equation estimated with real openness yields a coefficient that is positive and significant. Whatever effect Ropen has on productivity, it seems to be operating via $\mathrm{P}$, not via Open. So this more general framework yields little evidence that there is a significant causal effect from openness to productivity, holding the price level constant. Indeed, if we are to interpret these results literally, they suggest that causality runs from the price level to productivity.

${ }^{17}$ Staiger and Stock (1997) recommend a threshold value of 10 for the F-statistic to be confident that the instruments retain their validity. These results are available upon request.
} 
On this ground alone, then, the AC strategy introduces an additional distortion to the estimation. $^{18}$

In sum, we do not find the case for "real openness" particularly compelling. We worry that the "more robust" results that $\mathrm{AC}$ claim for it derive from the interaction of strong reverse causality with imperfections of the instrument.

\section{Dollar and Kraay (DK, 2002)}

Recently DK have analyzed the interaction between institutions, trade, and growth. ${ }^{19}$ They do so by estimating both level regressions and regressions where the dependent variable is the change in the growth rate of income. Their main argument for undertaking the second approach is the alleged multicollinearity between instruments for institutions and trade that militates against a proper disentangling of the two effects. That is, although institutions and trade are jointly significant in level regressions, it is difficult to identify the strength of the individual effects. Since our own results do not suggest multicollinearity to be a problem, we discuss the reasons for the difference.

Level regressions: Equation (1) in Table 7, which reproduces equation 12 in table 1 of DK, is the prime exhibit for their contention that the individual effects of trade and institutions cannot be disentangled. The estimated coefficients on institutions and trade are both insignificant which is allegedly a reflection of multicollinearity. (But notice that the coefficient on openness is negative!). It should be noted that DK follow AC by measuring integration as "real openness." In the subsequent columns labeled with asterisks, we show how non-robust this finding is, and conversely how robust is the finding relating to the primacy of institutions. Either deleting population from the DK specification (which is insignificant in any case) as in column (1) * or replacing "real openness" with openness (columns $(1)^{* *},(1)^{* * *}$, and $(1)^{* * * *}$ ) restores the importance of institutions (and with a vengeance as the very high t-values indicate), while openness remains insignificant. Also from Table 6, we know that our preferred specification is unaffected by inclusion of geography variables and by the use of "real openness."

${ }^{18}$ A little exploration reveals why the instruments work much better with openness than with real openness. The first stage regressions associated with estimating the equation described in footnote 13, which is based on the decomposition of real openness into openness and price, show that the first-stage for the price level equation has an F-statistic of 1.92. Apparently, the instruments do much worse with real openness because of the very weak correlation between the instrument set and the price level. Another issue is why AC use such an odd instrument list, entering the levels of population and land area, as well as their logs, whereas the secondstage equation has only the logs. It is hard to defend the idea that the level of land area, say, can be safely excluded from the second stage when its log belongs in it.

${ }^{19}$ Unlike EL, FR and our paper, DK place less emphasis on geography. 
Moreover, DK's own results with their larger, 134-country sample are fully consistent with ours: institutions are significant, "real openness" is not. This is shown in equation (2) in Table 7, which reproduces column (6) in DK's Table 1. DK argue that that the significance of the institutions variable in this larger sample is not robust to the exclusion of the 4 neo-European countries. (See equation (3) in Table 6, which corresponds to DK's column (7) in Table 1). DK provide no justification for why it is appropriate to exclude the neoEuropean countries from this sample. We have already established for our preferred sample (Table 3) that: (i) our results are robust to the exclusion of influential observations; (ii) there is no statistical reason to exclude the neo-European countries; and (iii) nevertheless, excluding them leaves our results unchanged. The columns with asterisks in Table 7 confirm this. In the larger sample with neo-Europes (columns $(2)^{*},(2)^{* *}$, and $(2)^{* * *}$ ) as well as in the sample without neo-Europes (columns (3)* and (3)**) institutions trump integration if the DK equations are estimated without population or if openness is used to replace "real openness".

Thus, the case that multicollinearity blurs the individual effects of trade and institutions is a hard one to make: it requires us to favor a problematic specification with an arbitrarily selected sample over all others, and to disregard much evidence to the contrary.

Change regressions: The DK change regressions are difficult to understand. The measures for institutional quality are puzzling and arbitrary, and the identification strategy not clearly justified. In Panel B of Table 7, we reproduce regressions involving each of their institutional variables. In each case, we re-estimate the equation adding time-region dummies. In every instance, the coefficients on real openness cease to be significant. What the results essentially indicate is that the 1980s were a lousy decade for Africa and Latin America and a good decade for Asia; there is no other information in these regressions beyond that. ${ }^{20}$

\section{What DoEs It ALL Mean?}

In this section, we evaluate and interpret our results further. This also gives us an opportunity to make some additional comments on the related literature. We group the comments under three headings. First, we argue that an instrumentation strategy should not be confused with

${ }^{20}$ More broadly, as Lant Pritchett has pointed out in his comments on the paper, the DK regressions are simply uninformative. That is, running these particular regressions with these instrument sets provides little information that would alter one's priors one way or the other. The appropriateness of some of the measures of institutional quality used by DKrevolutions and coups and war deaths, for example - is not clear, and it is highly doubtful that these are adequate instruments for measuring institutional change over time. Even leaving aside the insignificance of trade once time-region dummies are included, the instruments for institutions are simply too weak in these decadal regressions for the results to be of much use. 
building and testing theories. Second, we relate our discussion on institutions to the discussion on "policies." Third, we discuss the operational implications of the results.

\section{A. An Instrument Does Not a Theory Make}

Insofar as our results emphasize the supremacy of institutions, they are very close to those in AJR. Note that we have gone beyond AJR by using larger sample sizes, and by including measures of integration in our estimation. We want to highlight another possible difference, having to do with the interpretation of the results. In particular, we want to emphasize the distinction between using an instrument to identify an exogenous source of variation in the independent variable of interest and laying out a full theory of cause and effect. In our view, this distinction is not made adequately clear in AJR and is arguably blurred by Easterly and Levine (2002).

One reading of the AJR paper, and the one strongly suggested by their title - "The Colonial Origins of Comparative Development"-is that they regard experience under the early period of colonization as a fundamental determinant of current income levels. While the AJR paper is certainly suggestive on this score, in our view this interpretation of the paper's central message would not be entirely correct. One problem is that AJR do not carry out a direct test of the impact of colonial policies and institutions. Furthermore, if colonial experience were the key determinant of income levels, how would we account for the variation in incomes among countries that had never been colonized by the Europeans?

To illustrate the second point, Figure 5 presents histograms of per-capita incomes for 163 countries for which we have data on per-capita GDP in 1995. The sample is split into two groups, a group of 103 countries that were colonized by one of the major Western European powers sometime before the twentieth century, and a group of 60 countries that were not colonized. The latter group includes some very high-income countries such as Finland and Luxembourg as well very poor countries such as Ethiopia, ${ }^{21}$ Yemen, and Mongolia. (Afghanistan is another low-income non-colonized country, but we do not have income data for it). As the figure reveals, the dispersion of incomes within the colonized sample is not hugely different than that in the non-colonized sample. The standard deviations of log income per capita are 1.01 and 0.89 for the colonized and non-colonized samples, respectively. The income gaps that separate Ethiopia from Turkey, or China from Luxembourg are huge, and can obviously not be explained by any of these countries' colonial experience.

${ }^{21}$ Ethiopia was included in the AJR sample of colonies, even though this country has never been colonized. (It was occupied for a period of several years by Italy during 1936-1941, but this neither counts as colonization, nor could have had much to do with the settler mortality rates from the $19^{\text {th }}$ century). Excluding Ethiopia from the AJR sample makes no difference to the basic AJR results—and in fact it improves these results, as eyeballing AJR's Figures 1 and 2 would indicate. 
Where the AJR paper is successful is in the use of a plausible instrument to identify the causal relationship between institutional quality and income levels. An instrument is something that simply has some desirable statistical properties. It need not be a large part of the causal story. To illustrate the distinction between a theory and an instrument, here is an analogy that draws on a well-known paper by Angrist and Krueger (1991).

Angrist and Krueger (1991) use quarter of birth as an instrument for the level of educational attainment, to disentangle the effects of schooling on personal earnings from those of unobserved attributes (such as "ability"). The story is that compulsory schooling requirements, requiring schooling until age 16 or 17 , interacting with school-entry requirements, imply variation in the level of schooling that is correlated with quarter of birth but not with other personal attributes. The authors show for example that students born in the first quarter of the year have a systematically lower level of average schooling in the population. This is a plausible strategy for identification, but it obviously does not imply a quarter-of-birth theory of earnings. Similarly, the AJR strategy does not amount to a direct test of a colonial-origins theory of development. ${ }^{22}$

Easterly and Levine (2002) also assign a causal role to the settler mortality instrument and interpret it as a geographical determinant of institutions such as "crops and germs," rather than viewing it as a device to capture the exogenous source of variation in institutions. Indeed, although they stress the role of institutions, they appear to come close to a geography theory of development. Thus, both AJR and EL tend to elevate settler mortality beyond its status as an instrument, with AJR favoring a colonial view of development and EL a geography-based theory of development.

\section{B. The Primacy of Institutional Quality Does Not Imply Policy Ineffectiveness}

Easterly and Levine (2002) assert that (macroeconomic) policies do not have an effect on incomes, once institutions are controlled for. Our view on the effectiveness of policy is similar to that expressed in AJR $(1999,1395)$ : there are "substantial economic gains from improving institutions, for example as in the case of Japan during the Meiji Restoration or South Korea, during the 1960 s" or, one may add, China since the late 1970s. The distinction

${ }^{22}$ AJR themselves are somewhat ambiguous about this. They motivate settler mortality as an instrument, but then their account gravitates towards a colonial origins theory of institutional development. And their title strongly suggests that they consider the contribution of their paper to have been a theory as opposed to an identification strategy. In personal communication, one of the authors has explained that the colonial experience allows them to exploit the exogenous source of variation in institutions and not all the variation. The fit of the first-stage regressions of about 25 percent leaves room for most of the variation to be explained by factors other than colonization. 
between institutions and policies is murky, as these examples illustrate. The reforms that Japan, (South) Korea (that is, the Republic of Korea), and China undertook were policy innovations that eventually resulted in a fundamental change in the institutional underpinning of their economies.

We find it helpful to think of policy as a flow variable, in contrast to institutions, which is a stock variable. We can view institutions as the cumulative outcome of past policy actions. Letting $p_{i}$ denote policy on dimension $i$ ( $i=$ fiscal, trade, monetary, etc.), $I$ institutional quality, and $\delta$ the rate at which institutional quality decays absent countervailing action, the evolution of institutional quality over time can be written as $\dot{I}=\sum \alpha_{i} p_{i}-\delta I$, where $\alpha_{i}$ denotes the impact of policy $i$ on institutional quality.

This suggests that it is inappropriate to regress income levels on institutional quality and policies, as Easterly and Levine (2002) do. The problem is not just that incomes move slowly while policies can take sudden turns. In principle this could be addressed by taking long-term averages of policies. (Easterly and Levine average their policy measures over a number of decades.) It is that measures of institutional quality already contain all the relevant information about the impact of policies. If the appropriate specification for income is In $y=\beta I+u$, the effect of policies should be sought in a regression of the form $\mathrm{d} \ln y / \mathrm{d} t=\beta \dot{I}+v=\alpha_{0}+\beta \sum \alpha_{i} p_{i}+v$. In other words, one should look for the effect of policies in a regression of growth of income on policies.

Moreover, a geography theory of institutions can understate the impact that policies can play in changing them over time. As an empirical matter, institutions have changed remarkably in the last three decades. For example, one indicator of institutional quality-the index measuring the constraint on the executive in the Gurr Polity IV dataset, which is available on a consistent basis for several decades - shows a marked improvement between the 1970s and $1990 \mathrm{~s}$. For 71 countries in our core sample, this index had a mean value of 3.21 in the $1970 \mathrm{~s}$, 3.52 in the $1980 \mathrm{~s}$, and 4.37 in the $1990 \mathrm{~s}$. A purely geographical theory of institutions would have difficulty in accounting for these changes. Indeed, if the first stage regressions reported in Panel C of Table 2 are run over the last three decades, the coefficient on settler mortality, declines from 0.94 in the 1970 s to 0.87 in the $1980 \mathrm{~s}$ and 0.71 in the $1990 \mathrm{~s}$, illustrating the mutability of institutions, and the declining importance of history (on the AJR interpretation of settler mortality) or geography (on the EL interpretation of settler mortality) in explaining the cross-national variation in institutions.

\section{The Hard Work Is Still Ahead}

How much guidance do our results provide to policymakers who want to improve the performance of their economies? Not much at all. Sure, it is helpful to know that geography is not destiny, or that focusing on increasing the economy's links with world markets is unlikely to yield convergence. But the operational guidance that our central result on the primacy of institutional quality yields is extremely meager. 
Our indicators of institutional quality are investors' and other observers' ratings of the institutional environment. They quantify these observers' views as to the likelihood that investors will retain the fruits of their investments, the chances that the state will expropriate them, or that the legal system will protect their property rights. While it is important to know that these ratings matter-and matter a great deal in fact-it remains unclear how the underlying evaluations and perceptions can be altered. In terms of the formulation developed above, what we have estimated is $\beta$, while what policy makers need to know are the $\alpha_{i}$ (policy impacts) for the policies at their disposal. In fact, since our identification strategies rely on exogenous sources of variation in these evaluations, they are doubly unhelpful from a policy perspective.

We illustrate the difficulty of extracting policy-relevant information from our findings using the example of property rights. Obviously, the presence of clear property rights for investors is a key, if not the key, element in the institutional environment that shapes economic performance. Our findings indicate that when investors believe their property rights are protected, the economy ends up richer. But nothing is implied about the actual form that property rights should take. We cannot even necessarily deduce that enacting a private property-rights regime would produce superior results compared to alternative forms of property rights.

If this seems stretching things too far, consider the experiences of China and Russia. China still retains a socialist legal system, while Russia has a regime of private property rights in place. Despite the absence of formal private property rights, Chinese entrepreneurs have felt sufficiently secure to make large investments, making that country the world's fastest growing economy over the last two decades. In Russia, by contrast, investors have felt insecure, and private investment has remained low. Our institutional quality indicators bear this out, with Russia scoring considerably lower than China despite a formal legal regime that is much more in line with European norms than China's. Credibly signaling that property rights will be protected is apparently more important than enacting them into law as a formal private property rights regime.

So our findings do not map into a determinate set of policy desiderata. Indeed, there is growing evidence that desirable institutional arrangements have a large element of context specificity, arising from differences in historical trajectories, geography, political economy, or other initial conditions. As argued in Mukand and Rodrik (2002), this could help explain why successful developing countries-China, the Republic of Korea, and Taiwan Province of China among others-have almost always combined unorthodox elements with orthodox policies. It could also account for why important institutional differences persist among the advanced countries of North America, Western Europe, and Japan - in the role of the public sector, the nature of the legal systems, corporate governance, financial markets, labor markets, and social insurance mechanisms, among others.

It is important to underscore that this does not mean economic principles work differently in different places. We need to make a distinction between economic principles and their institutional embodiment. Most first-order economic principles come institution-free. 
Economic ideas such as incentives, competition, hard-budget constraints, sound money, fiscal sustainability, property rights do not map directly into institutional forms. Property rights can be implemented through common law, civil law, or, for that matter, Chinese-type socialism. Competition can be maintained through a combination of free entry and laissezfaire, or through a well-functioning regulatory authority. Macroeconomic stability can be achieved under a variety of fiscal institutions. Institutional solutions that perform well in one setting may be inappropriate in other setting without the supporting norms and complementary institutions. In the words of Douglass North:

"economies that adopt the formal rules of another economy will have very different performance characteristics than the first economy because of different informal norms and enforcement. The implication is that transferring the formal political and economic rules of successful Western economies to third-world and Eastern European economies is not a sufficient condition for good economic performance." (North $1994,366)$

In addition, since policy makers always operate in second-best environments, optimal reform trajectories - even in apparently straightforward cases such as price reform-cannot be designed without regard to prevailing conditions and without weighting the consequences for multiple distorted margins.

Consequently, there is much to be learned still about what improving institutional quality means on the ground. This, we would like to suggest, is a wide open area of research. Crossnational studies of the present type are just a beginning that point us in the right direction. 
Figure 1. The "Deep" Determinants of Income

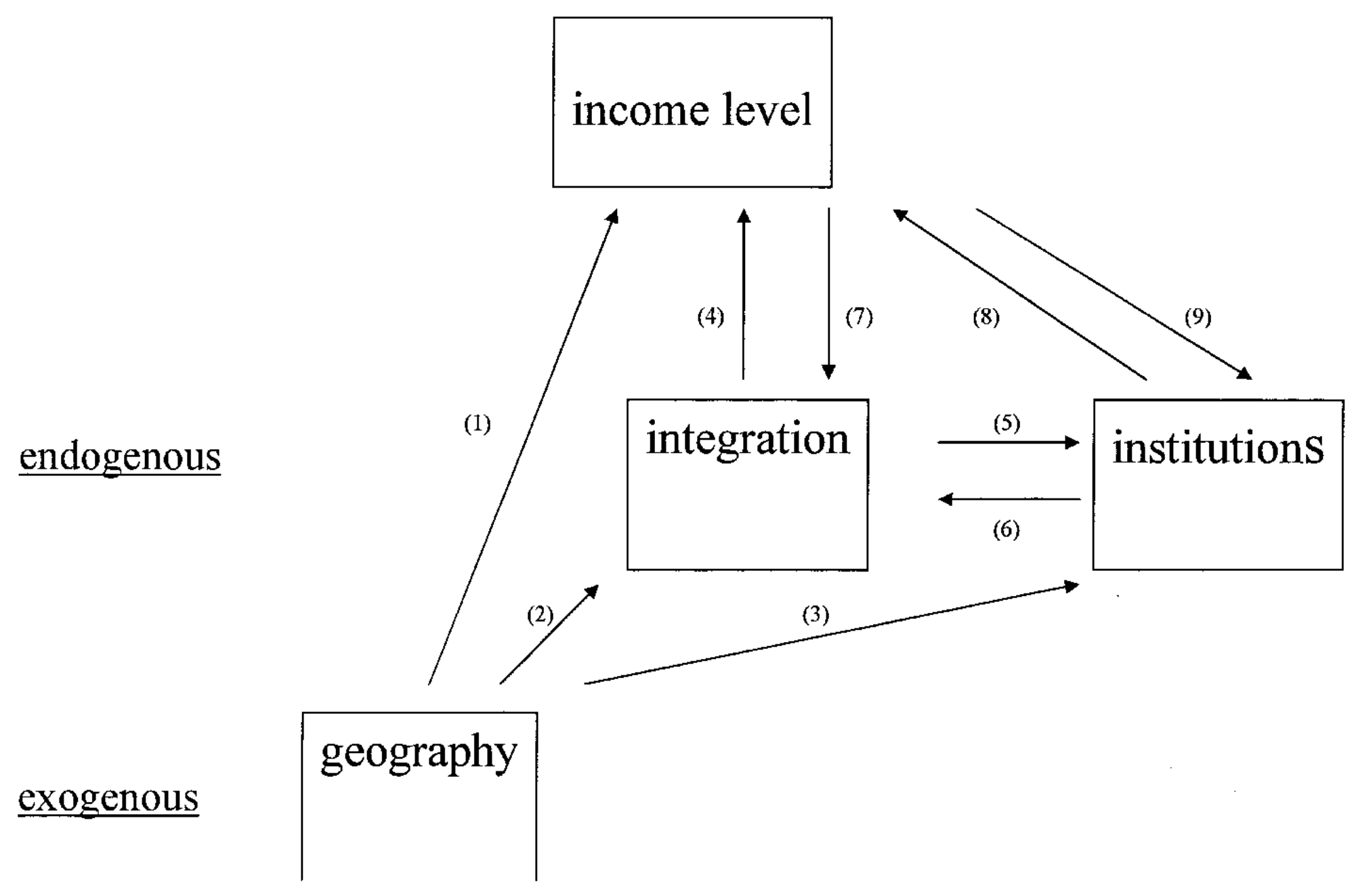


Figure 2. Simple Correlations Between Income and Its Determinants

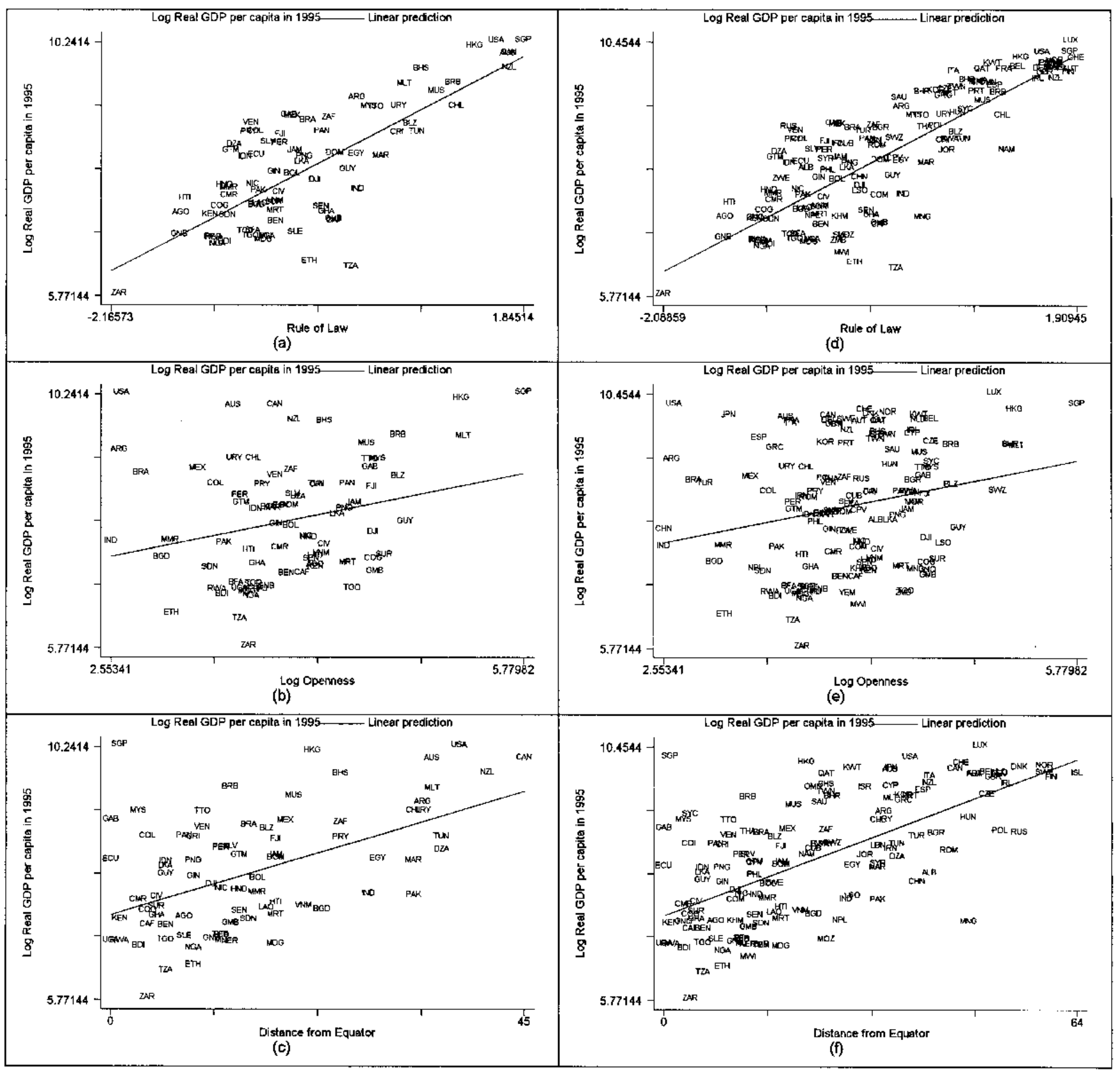

Source: Authors' estimates.

Note: Sample of 80 countries for panels (a), (b), and (c) and sample of 140 countries for panels (d), (e), and (f). 
Figure 3. Conditional Correlations Between Income and Its Determinants

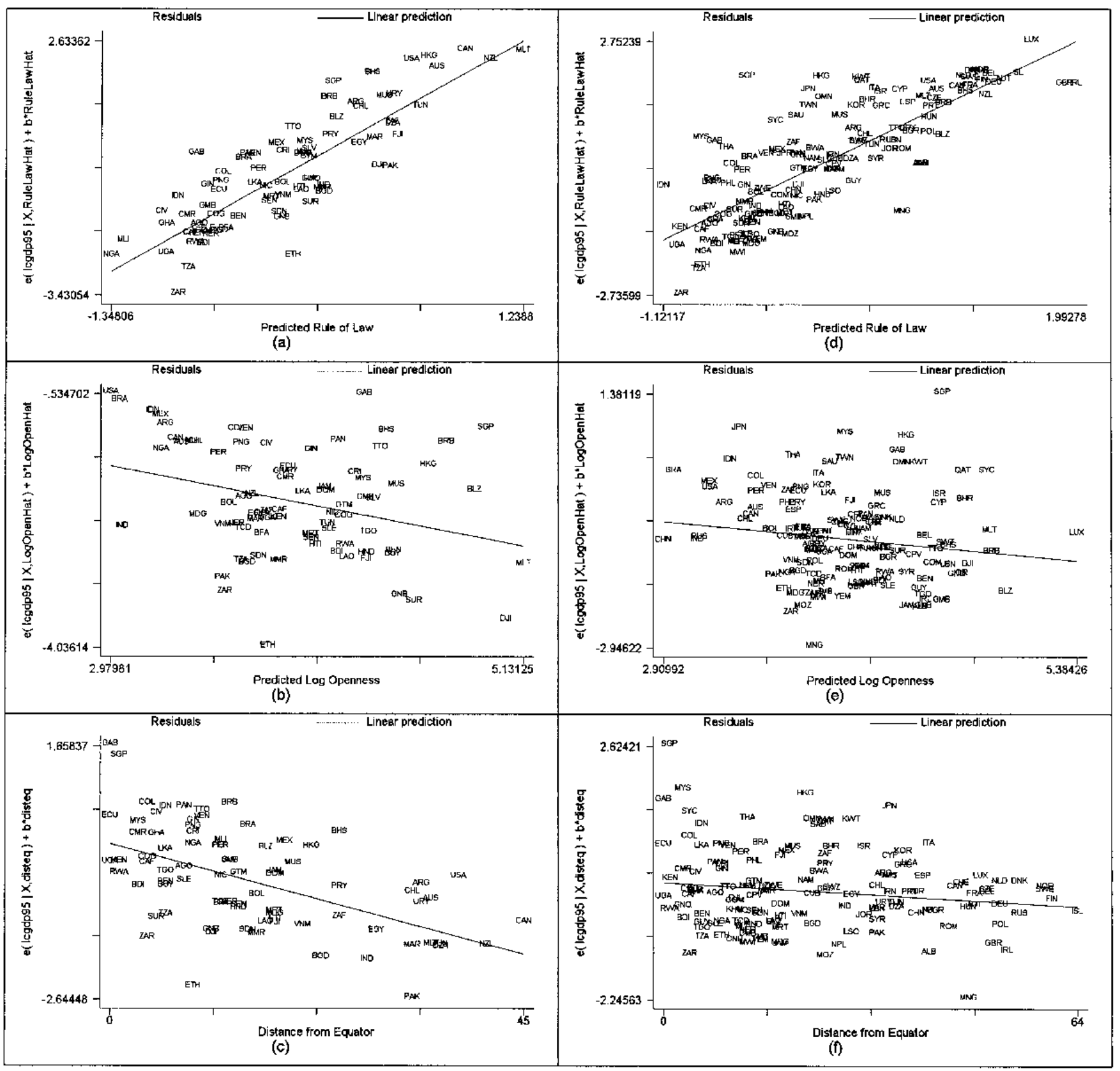

Source: Authors' estimates.

Note: Sample of 80 countries for panels (a), (b), and (c)and sample of 140 countries for panels (d), (e), and (f)). The slopes of the linear prediction in (a), (b), and (c) above correspond to the (unstandardized) coefficients in column (6) of Table 2, while those in (d), (e), and (f) correspond to the (unstandardized) coefficients in column (9) of Table 2. 
Figure 4. "Real Openness," Openness, and Income

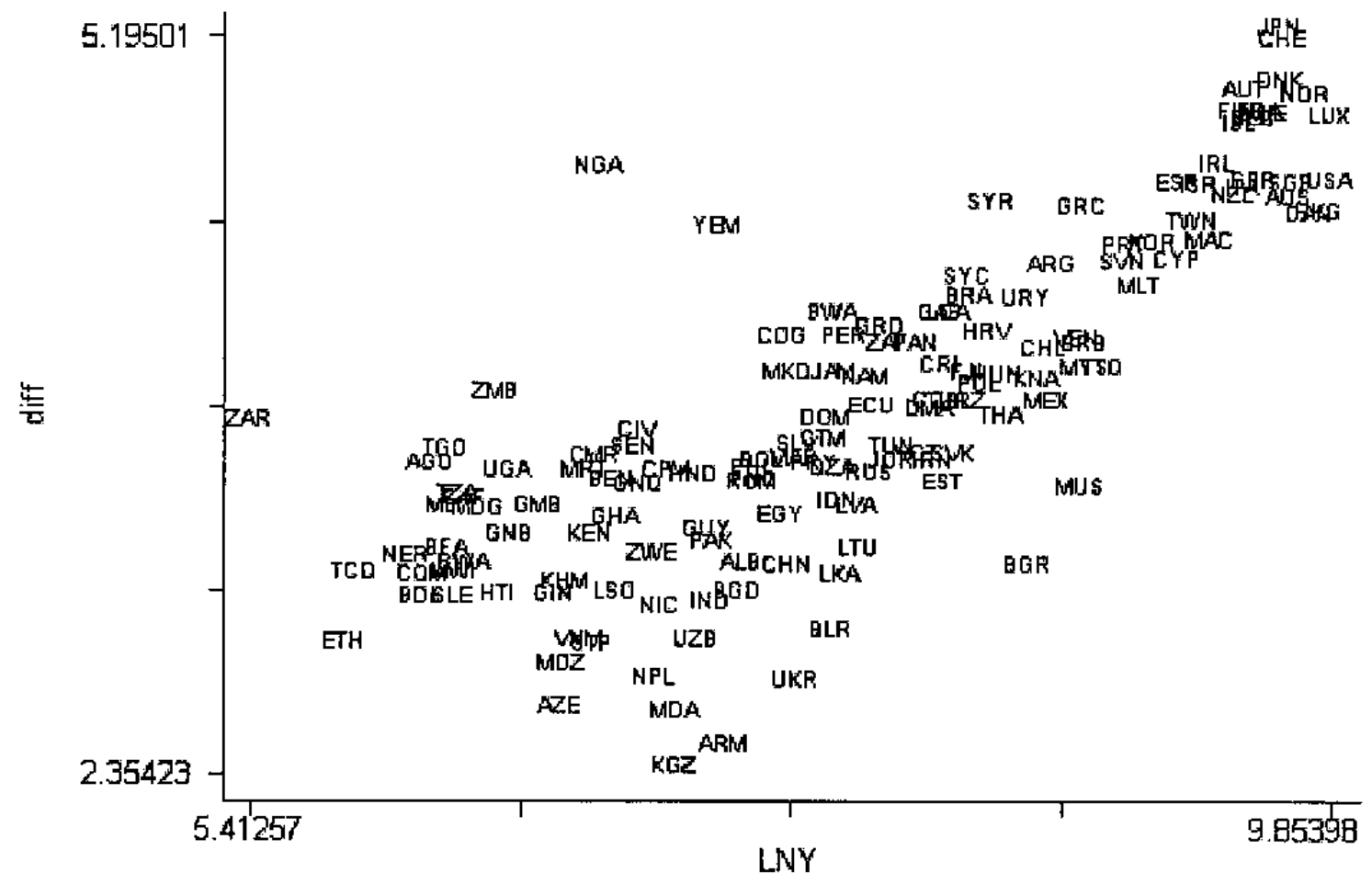

Source: Authors' estimates.

Note: Difference between logs of "real openness" and openness on the vertical axis and log per capita PPP GDP on the horizontal axis. 
Figure 5. Distribution of Incomes for Colonized and Noncolonized countries

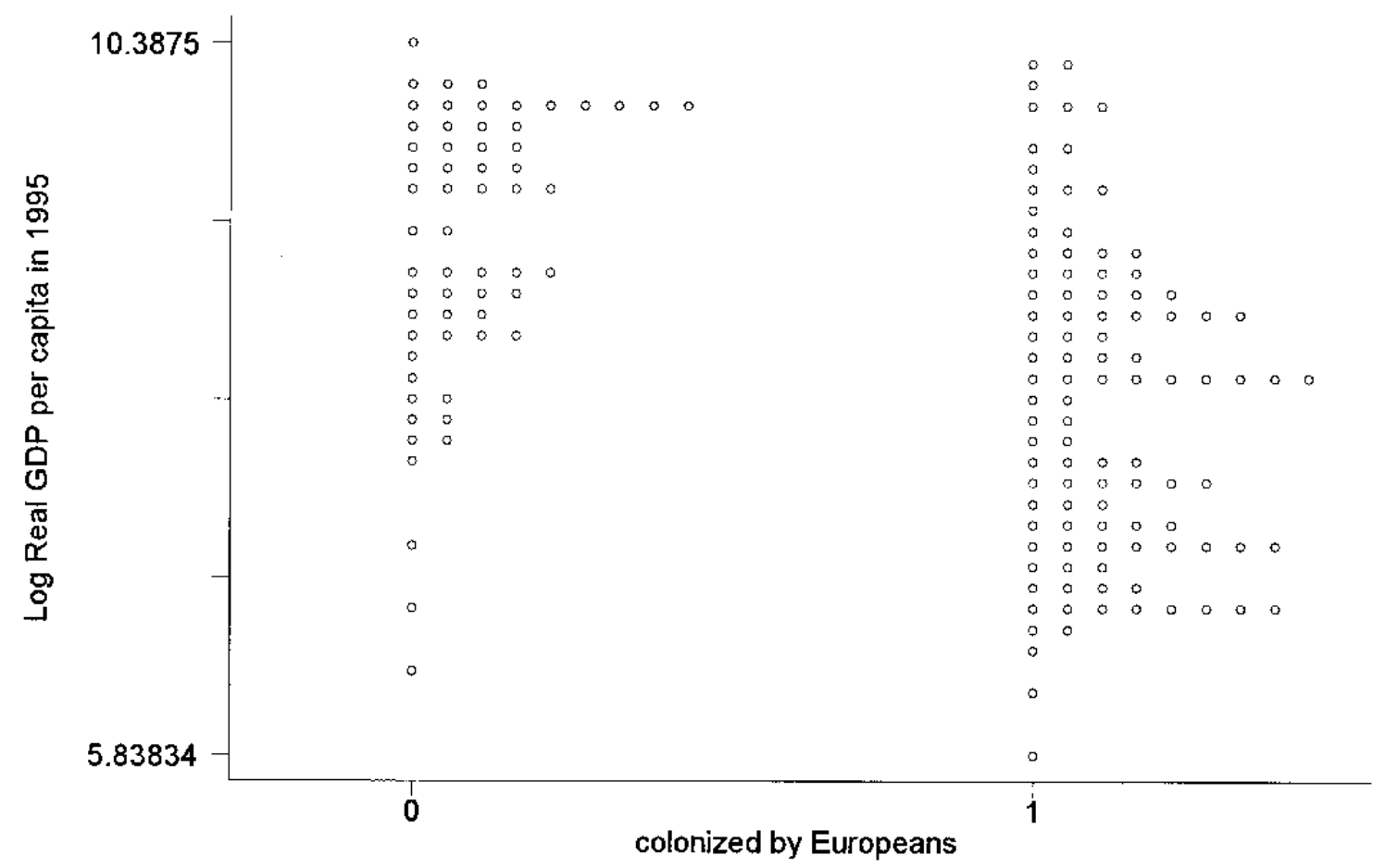


Table 1. Descriptive Statistics

Panel A: Mean and Standard Deviations of Key Variables

\begin{tabular}{lcc}
\hline & $\begin{array}{c}\text { Extended AJR } \\
\text { Sample } \\
\text { (80 countries) }\end{array}$ & $\begin{array}{c}\text { Large Sample } \\
\text { (140 countries) }\end{array}$ \\
\hline Log GDP per capita (PPP) in 1995 (LCGDP95) & 8.01 & 8.40 \\
& 1.05 & 1.14 \\
Rule of law (RULE) & -0.25 & 0.89 \\
& 0.85 & 0.94 \\
Log openness (LCOPEN) & & 4.01 \\
& 3.94 & 0.57 \\
Distance from equator in degrees (DISTEQ) & 0.60 & 23.60 \\
& & 16.29 \\
Log European settler mortality (LOGEM4) & 15.23 &.. \\
(deaths per annum per 1000 population) & 11.16 &.. \\
Log constructed openness (LOGFRANKROM) & & 2.92 \\
& 1.22 & 0.80 \\
Fraction of population speaking & 2.76 & 0.24 \\
other European language (EURFRAC) & 0.76 & 0.39 \\
English (ENGFRAC) & & 0.08 \\
\hline
\end{tabular}

Notes: Standard deviations are reported below the means. Rule of law ranges between -2.5 and +2.5 . Openness is measured as the ratio of trade to GDP. Constructed openness - the instrument for openness-is the predicted trade share and is from Frankel and Romer (1999). Appendix II describes in delail all the data and their sources. 
Panel B: Pairwise Correlations

\begin{tabular}{|c|c|c|c|c|c|c|c|c|}
\hline & LCGDP95 & RULE & LCOPEN & LOGFRANKROM & DISTEQ & LOGEM4 & EURFRAC & ENGFRAC \\
\hline LCGDP95 & 1 & & & & & & & \\
\hline \multirow[t]{2}{*}{ RULE } & 0.763 & 1 & & & & & & \\
\hline & 0.000 & & & & & & & \\
\hline \multirow[t]{2}{*}{ LCOPEN } & 0.260 & 0.263 & 1 & & & & & \\
\hline & 0.020 & 0.018 & & & & & & \\
\hline \multirow{2}{*}{ LOGFRANKROM } & -0.043 & 0.026 & 0.734 & 1 & & & & \\
\hline & 0.703 & 0.821 & 0.000 & & & & & \\
\hline \multirow[t]{2}{*}{ DISTEQ } & 0.513 & 0.520 & -0.207 & -0.292 & 1 & & & \\
\hline & 0.000 & 0.000 & 0.065 & 0.009 & & & & \\
\hline \multirow[t]{2}{*}{ LOGEM4 } & -0.685 & -0.540 & -0.093 & 0.155 & -0.491 & 1 & & \\
\hline & 0.000 & 0.000 & 0.410 & 0.169 & 0.000 & & & \\
\hline \multirow[t]{2}{*}{ EURFRAC } & 0.612 & 0.438 & -0.071 & -0.128 & 0.276 & -0.344 & 1 & \\
\hline & 0.000 & 0.000 & 0.530 & 0.258 & 0.013 & 0.002 & & \\
\hline \multirow[t]{2}{*}{ ENGFRAC } & 0.491 & 0.544 & 0.153 & 0.018 & 0.303 & -0.325 & 0.575 & 1 \\
\hline & 0.000 & 0.000 & 0.175 & 0.876 & 0.006 & 0.003 & 0.000 & \\
\hline
\end{tabular}

Notes: Correlations are reported for the sample of 80 countries. $p$-values reported below the coefficients. Variables described in Appendix II. 
Table 2: Determinants of Development: Core Specifications

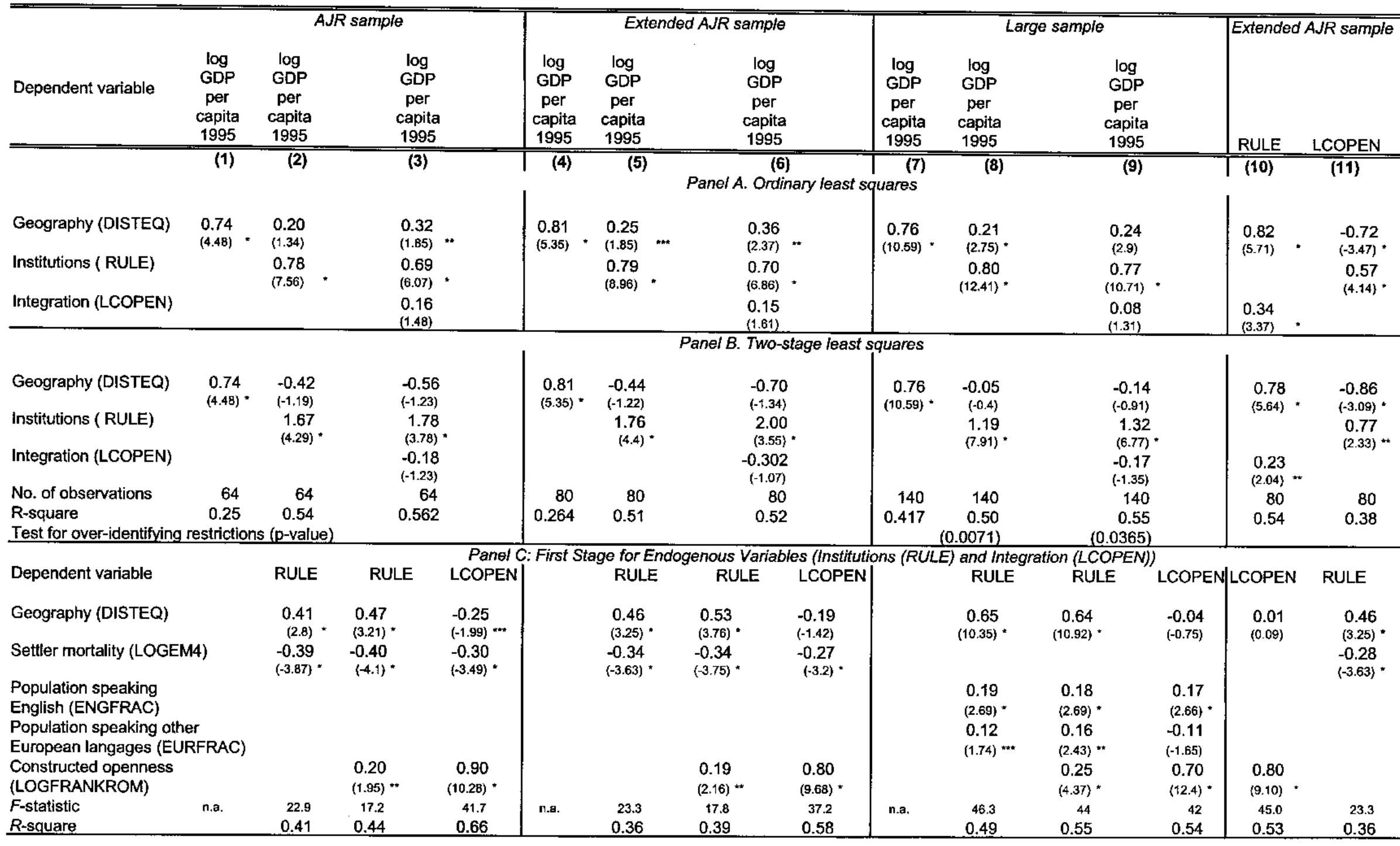


Source: Authors' estimates.

Notes: The dependent variable in Panels A and B are per capita GDP in 1995, PPP basis. There are three samples for which the core regressions are run: (i) the first three columns correspond to the sample of 64 countries in Acemoglu, Johnson, and Robinson (2001; AJR); (ii) columns (4) to (6) use a sample of 80 countries for which data on settler mortality (LOGEM4) have been compiled by AJR; and (iii) columns (7) to (9) use a larger sample of 140 countries for which the instrument for institutions is that in Dollar and Kraay (2002; DK) but is also similar to that in Hall and Jones (1998). The regressors in Panels A and B are: (i) DISTEQ, the variable for geography, which is measured as the absolute value of latitude of a country; (ii) Rule of law (RULE), which is the measure for institutions; and (iii) LCOPEN, the variable for integration, which is measured as the ratio of nominal trade to nominal GDP. All regressors are scaled in the sense that they represent deviations from the mean divided by the standard deviation. The dependent variables in Panel $\mathrm{C}$ are measures of institutions (RULE) and/or integration (LCOPEN) depending on the specification. The regressors in Panel C are: (i) DISTEQ described above; (ii) settler mortality (LOGEM4) in the first six columns; (iii) the proportion of the population of a country that speaks English (ENGFRAC) and the proportion of the population that speaks any European language (EURFRAC) in the last three columns; (iv) instrument for openness (LOGFRANKROM) obtained from Frankel and Romer (1999). All regressors, except DISTEQ and RULE, in the three panels are in logs. See Appendix II for more detailed variable definitions and sources. Standard errors are corrected, using the procedure described in Frankel and Romer (1999), to take into account the fact that the openness instrument is estimated. T-statistics are reported under coefficient estimates. Significance at the 1 percent, 5 percent, and 10 percent levels are denoted respectively by “*”, "**”, and “***”. 
Table 3. Determinants of Development: Channels of Influence

\begin{tabular}{|c|c|c|c|c|c|c|c|c|}
\hline \multirow{2}{*}{ Dependent variable } & \multicolumn{4}{|c|}{ Extended AJR sample } & \multicolumn{4}{|c|}{ Larger sample } \\
\hline & $\begin{array}{l}\text { come pe } \\
\text { lorker }\end{array}$ & $\begin{array}{l}\text { Capital per } \\
\text { worker }\end{array}$ & $\begin{array}{l}\text { Human capital } \\
\text { per worker }\end{array}$ & $\begin{array}{l}\text { Total factor } \\
\text { productivity }\end{array}$ & $\begin{array}{l}\text { Income per } \\
\text { worker }\end{array}$ & $\begin{array}{l}\text { Capital per } \\
\text { worker }\end{array}$ & $\begin{array}{c}\text { Human capital } \\
\text { per worker }\end{array}$ & $\begin{array}{l}\text { Total factor } \\
\text { productivity }\end{array}$ \\
\hline Geography (DISTEQ) & $\begin{array}{l}-0.94 \\
(-1.47)\end{array}$ & $\begin{array}{l}-1.68 \\
(-1.59)\end{array}$ & $\begin{array}{l}-0.25 \\
(-1.5)\end{array}$ & $\begin{array}{l}-0.32 \\
(-0.97)\end{array}$ & $\begin{array}{l}-0.26 \\
(-1.15)\end{array}$ & $\begin{array}{l}-0.39 \\
(-1.11)\end{array}$ & $\begin{array}{l}-0.05 \\
(-0.91)\end{array}$ & $\begin{array}{l}-0.14 \\
(-0.89)\end{array}$ \\
\hline Institutions ( RULE) & $\begin{array}{l}2.22 \\
(3.29)\end{array}$ & $\begin{array}{l}3.41 \\
(3.01)^{*}\end{array}$ & $\begin{array}{l}0.57 \\
(3.14)^{*}\end{array}$ & $\begin{array}{l}1.06 \\
(3.08) *\end{array}$ & $\begin{array}{l}1.36 \\
(5.01)^{*}\end{array}$ & $\begin{array}{l}1.95 \\
(4.5)^{*}\end{array}$ & $\begin{array}{l}0.35 \\
(5.21)\end{array}$ & $\begin{array}{l}0.72 \\
(3.7) *\end{array}$ \\
\hline Integration (LCOPEN) & $\begin{array}{l}-0.41 \\
(-1.31)\end{array}$ & $\begin{array}{l}-0.68 \\
(-1.26)\end{array}$ & $\begin{array}{l}-0.15 \\
(-1.84)\end{array}$ & $\begin{array}{l}-0.13 \\
(-0.79)\end{array}$ & $\begin{array}{l}-0.36 \\
(-2.27) *\end{array}$ & $\begin{array}{l}-0.53 \\
(-2.34)^{* *}\end{array}$ & $\begin{array}{l}-0.12 \\
(-3.19)^{*}\end{array}$ & $\begin{array}{l}-0.15 \\
(-1.27)\end{array}$ \\
\hline $\begin{array}{l}\text { R-square } \\
\text { No of observations }\end{array}$ & $\begin{array}{r}0.60 \\
.74 \\
\end{array}$ & $\begin{array}{r}0.52 \\
74 \\
\end{array}$ & $\begin{array}{r}0.52 \\
74 \\
\end{array}$ & $\begin{array}{r}0.45 \\
74 \\
\end{array}$ & $\begin{array}{l}0.58 \\
122 \\
\end{array}$ & $\begin{array}{r}0.54 \\
122 \\
\end{array}$ & $\begin{array}{r}0.59 \\
122 \\
\end{array}$ & $\begin{array}{l}0.35 \\
122 \\
\end{array}$ \\
\hline
\end{tabular}

Source: Authors' estimates.

Notes: The four dependent variables-income per worker, capital per worker, human capital per worker, and the level of total factor productivity--are expressed in natural logarithms and are from Hall and Jones (1999). IV estimates for the AJR sample use settler mortality (LOGEM4) as the instrument for institutions and EURFRAC and ENGFRAC as the instnument for the larger sample. All regressors, except RULE, are in logarithms and are scaled. Standard errots are corrected, using the procedure described in Frankel and Romer (1999), to take into account the fact that the openness instrument is estimated. T-statistics are reported under coefficient estimatcs. Significance at the 1 percent, 5 percent, and 10 percent levels are denoted respectively by “*”, "**", and "***". 
Table 4. Determinants of Development: Robustness to "Influential" Observations, Neoeuropes, Legal Systems, Origin of Colonizer, and Religion

\begin{tabular}{|c|c|c|c|c|c|c|c|c|c|c|c|c|c|c|}
\hline & Baseline 1 & $(1)^{*}$ & $(1)^{\star * *}$ & $(1)^{\star * *}$ & $(1)^{\star \star \star \star}$ & Baseline 2 & $(2)^{\star}$ & $(2)^{\star \star}$ & $(2)^{\star \star \star \star}$ & (3) & (4) & & $(5)$ & \\
\hline \multicolumn{15}{|c|}{ Two-stage least squares: Dependent variable is log GDP per capita in 1995} \\
\hline Geography (DISTEQ) & $\begin{array}{l}-0.70 \\
(-1.34)\end{array}$ & $\begin{array}{l}-1.34 \\
(-1.08)\end{array}$ & $\begin{array}{l}-0.66 \\
(-1.38)\end{array}$ & $\begin{array}{l}-0.90 \\
(-1.14)\end{array}$ & $\begin{array}{l}-0.58 \\
(-0.81)\end{array}$ & $\begin{array}{l}-0.14 \\
(-0.91)\end{array}$ & $\begin{array}{l}-0.14 \\
(-0.91)\end{array}$ & $\begin{array}{l}0.02 \\
(0.17)\end{array}$ & $\begin{array}{l}-0.36 \\
(+2.12)^{\star *}\end{array}$ & $\begin{array}{l}-0.96 \\
(-1.45)\end{array}$ & $\begin{array}{r}-0.67 \\
(-0.98)\end{array}$ & & $\begin{array}{r}-0.81 \\
(-1.27)\end{array}$ & \\
\hline Instilutions (RULE) & $\begin{array}{l}2.00 \\
(3.55)^{*}\end{array}$ & $\begin{array}{l}2.68 \\
(3.03)\end{array}$ & $\begin{array}{c}1.82 \\
(3.31)\end{array}$ & $\begin{array}{l}2.82 \\
(2.43)^{\star \star}\end{array}$ & $\begin{array}{l}1.97 \\
(1.67)^{\star *+*}\end{array}$ & $\begin{array}{l}1.32 \\
(6.77)^{*}\end{array}$ & $\begin{array}{l}1.32 \\
(6.77)^{*}\end{array}$ & $\begin{array}{l}0.90 \\
(8.47)^{*}\end{array}$ & $\begin{array}{l}1.69 \\
(4.87)^{*}\end{array}$ & $\begin{array}{l}2.43 \\
(3.09)^{*}\end{array}$ & $\begin{array}{l}2.22 \\
(2.56)\end{array}$ & . & $\begin{array}{c}2.13 \\
(2,97)\end{array}$ & * \\
\hline !ntegration (LCOPEN) & $\begin{array}{r}-0.302 \\
(-1.07)\end{array}$ & $\begin{array}{l}-0.44 \\
(-1.68)\end{array}$ & $\begin{array}{l}-0.31 \\
(-1.23)\end{array}$ & $\begin{array}{l}-0.75 \\
(-1.30)\end{array}$ & $\begin{array}{l}-0.42 \\
(-0.81)\end{array}$ & $\begin{array}{l}-0.17 \\
(-1.35)\end{array}$ & $\begin{array}{l}-0.17 \\
(-1.35)\end{array}$ & $\begin{array}{c}0.03 \\
(0.25)\end{array}$ & $\begin{array}{l}-0.36 \\
(-1.46)\end{array}$ & $\begin{array}{l}-0.41 \\
(-1.50)\end{array}$ & $\begin{array}{c}-0.23 \\
(-0.79)\end{array}$ & & $\begin{array}{r}-0.32 \\
(-1.12)\end{array}$ & \\
\hline \multicolumn{15}{|l|}{ REGIONAL DUMMIES } \\
\hline Latin America (LAAM) & & & $\begin{array}{l}0.44 \\
(1.25)\end{array}$ & & $\begin{array}{c}0.17 \\
(0.33)\end{array}$ & & & $\begin{array}{c}0.25 \\
(1.655)^{\star \star \star *}\end{array}$ & & & & & & \\
\hline Sub-Saharan Africa (SA & FRICA) & & $\begin{array}{l}-0.19 \\
(-0.51)\end{array}$ & & $\begin{array}{l}-0.43 \\
(-1.11)\end{array}$ & & & $\begin{array}{l}-0.63 \\
(-3.79)^{*}\end{array}$ & & & & & & \\
\hline East Asia (ASIAE) & & & $\begin{array}{c}0.24 \\
(0.56)\end{array}$ & & $\begin{array}{l}0.07 \\
(0.14)\end{array}$ & & & $\begin{array}{c}0.12 \\
(0.62)\end{array}$ & & & & & & \\
\hline Legal origin & & & & & & & & & & [0.133] & & & & \\
\hline Identity of colonizer & & & & & & & & & & & {$[0.058]$} & $* * *$ & & \\
\hline Religion & & & & & & & & & & & & & [0.019] & $* *$ \\
\hline$R$-square & 0.52 & 0.56 & 0.65 & 0.44 & 0.63 & 0.55 & 0.55 & 0.67 & 0,55 & 0.53 & 0.56 & & 0.59 & \\
\hline No. of observations & 80 & 78 & 79 & 76 & 76 & 140 & 140 & 137 & 136 & 80 & 80 & & 80 & \\
\hline Omitted observations & None & $\begin{array}{l}\text { Singapore } \\
\text { Ethiopia }\end{array}$ & Ethiopia & $\begin{array}{l}\text { Australia } \\
\text { Canada } \\
\text { New Zealand } \\
\text { USA }\end{array}$ & $\begin{array}{l}\text { Australia } \\
\text { Canada } \\
\text { New Zealand } \\
\text { USA }\end{array}$ & None & None & $\begin{array}{l}\text { Cuba } \\
\text { Czech Rep. } \\
\text { Germany }\end{array}$ & $\begin{array}{l}\text { Australia } \\
\text { Canada } \\
\text { New Zealand } \\
\text { USA }\end{array}$ & None & None & & None & \\
\hline
\end{tabular}

Source: Authors' estimates.

Notes: The dependent variable is per capita GDP in 1995, PPP basis. Baseline 1 corresponds to the specification in colunn (6) of Table 2. Basel ine 2 corresponds to the specification in column (9) of Table 2. In columns labeled with 1 and 2 asterisks, influential observations are defined according to the Belsey, Kuh, and Welsch (1980) DFITS statistic, which requires omitting those observations for which DFITS exceeds $2(\mathrm{k} / \mathrm{n})^{\Upsilon}(1 / 2)$, where $\mathrm{k}$ is the number of regressors and $\mathrm{n}$ is the sample size. In columns labeled with three or four asterisks, observations for Australia, Canada, New Zealand, and Canada (Neoeuropes) are omitted. Standard errors are corrected, using the procedure described in Frankel and Romer (1999), to take into account the fact that the openness instrument is estimated. Tstatistics are reported under coefficient estimates. For legal origin, identity of colonizer, and religion, p-values for joint significance of the underlying variables (LEGFR and LEGSO for legal origin, COLUK and COLFR for colonizer's identity, and CATH, PROT, and MUSL for religion) are reported. Significance at the 1 percent, 5 percent, and 10 percent levels are denoted respectively by "**, “**”, and "***". All regressors are scaled as described in the notes to Tablc 2 . 
Table 5. Determinants of Development: Robustness to Alternative Measures of Geography

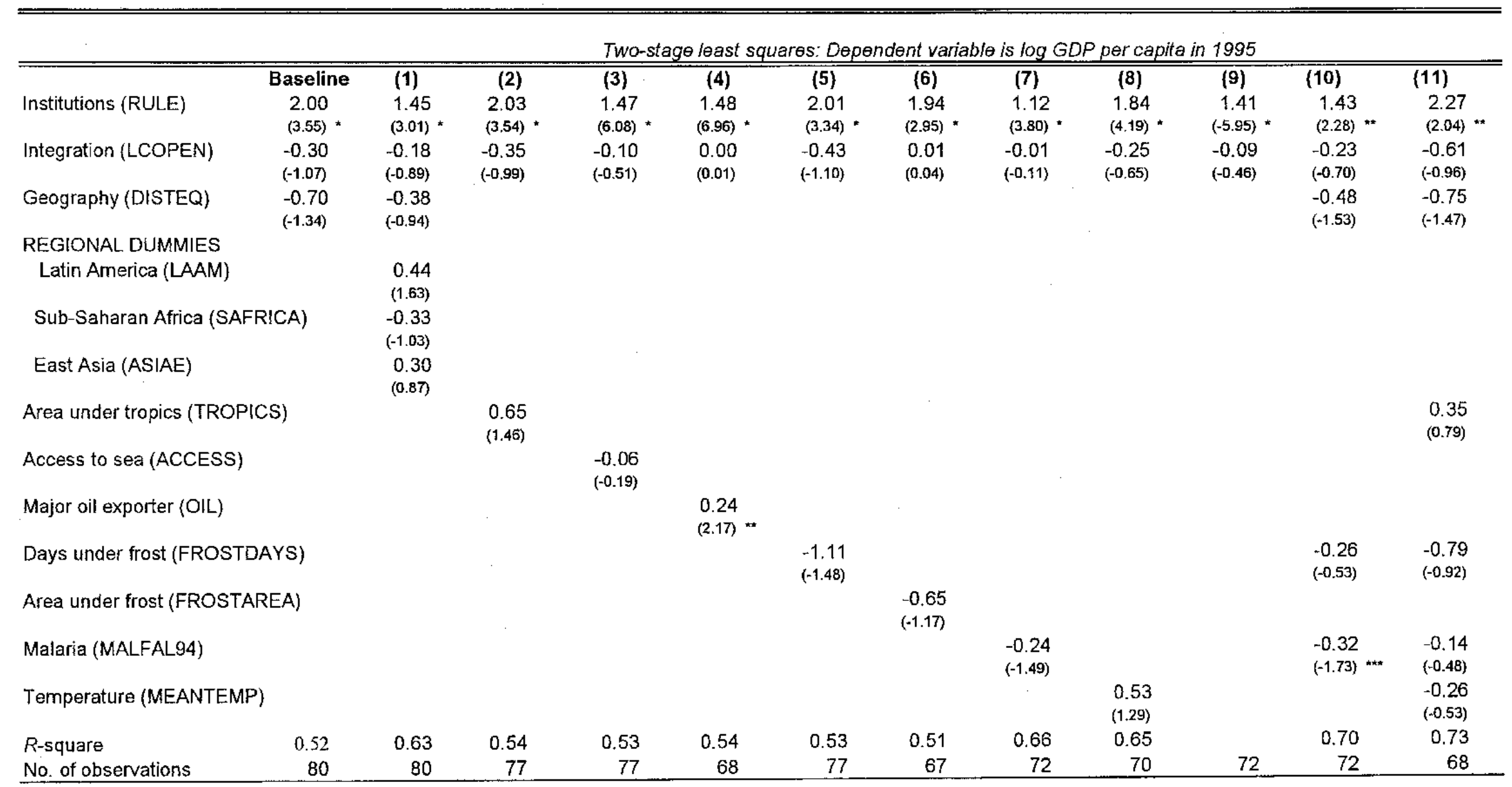

Source: Authors' estimates.

Notes: The dependent variable is per capita GDP in 1995, PPP basis. Bascline corresponds to the specification in column (6) of Table 2. Standard errors are corrected, using the procedure described in Frankel and Romer (1999), to take into account the fact that the openness instrument is estimated. t-statistics are reported under coeflicient estimates. Significance at the 1 percent, 5 percent, and 10 percent levels are denoted respectively by "**, "***", and "****". 
Table 6. Determinants of Development: Robustness to Alternative Measures of, and Instruments for, Integration

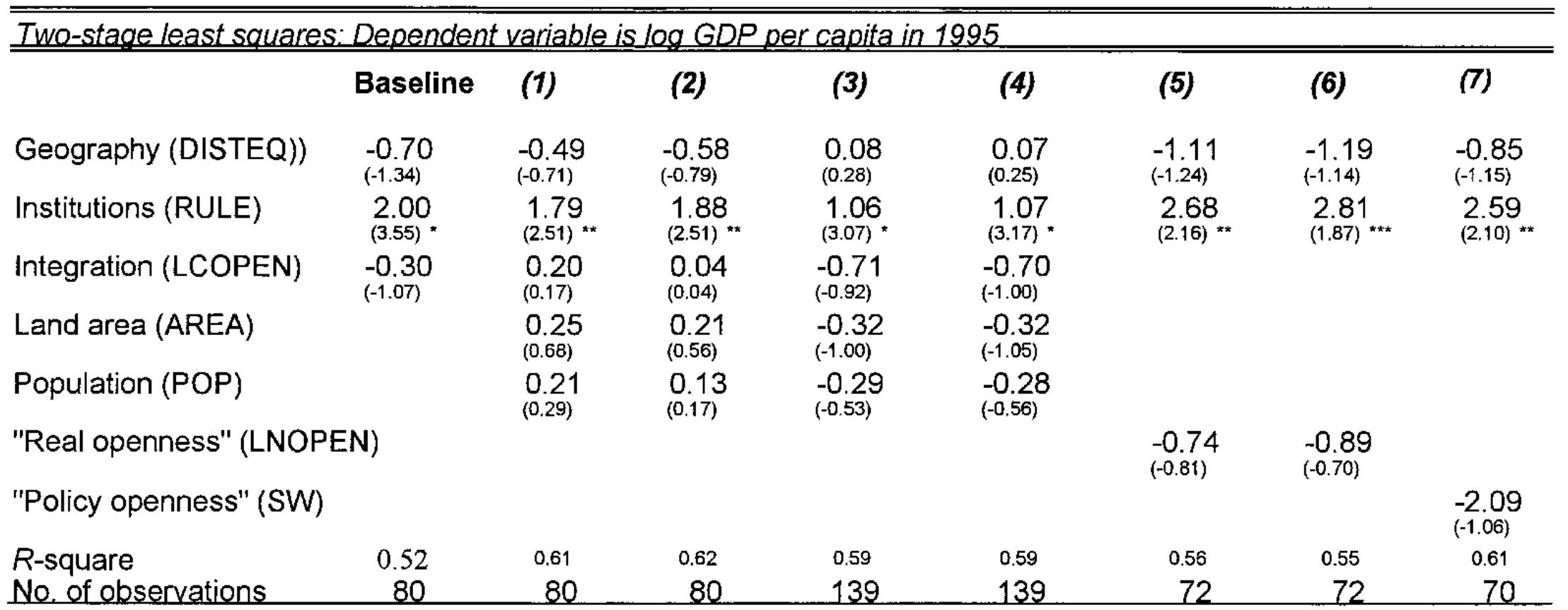

Source: Authors' estimates.

Notes: The dependent variable is per capita GDP in 1995, PPP basis. All regressors, except DISTEQ, RULEE, and SW, are expressed in logs. Baseline corresponds to the specification in column (6) of Table 2. In columns (1), (3) and (5) the instrument for openness (LOGFRANKROM) is from Frankel and Romer (1999). In columns (2), (4) and (6), the instrument for openness (LOGFRANKROMR) is derived by re-estimating the gravity equation in Frankel and Romer (1999) with the left-hand side variable defined as nominal bilateral trade to nominal GDP. In FR, the left hand side variable was defined as nominal trade divided by PPP GDP. Standard errors are corrected, using the procedure described in Frankel and Romer (1999), to take into account the fact that the openness instrument is estimated. t-statistics are reported under coefficient estimates. Significance at the 1 percent, 5 percent, and 10 percent levels are denoted respectively by "**", "***”, and "“***". All regressors are scalcd as described in the notes to Table 2. 
Table 7. Robustness of Dollar-Kray Results

\begin{tabular}{|c|c|c|c|c|c|c|c|c|c|c|c|}
\hline \multicolumn{12}{|c|}{ Panel A. Two-stage least squares: dependent variable is log GDP per capita in 1995} \\
\hline & (1) & $(1)^{*}$ & $(1)^{* *}$ & $(1)^{* * *+}$ & $(1)^{* * * * *}$ & (2) & $(2)^{*}$ & $(2)^{* *}$ & (3) & $(3)^{*}$ & $\{3\}^{\star \star}$ \\
\hline Institutions (RULE) & $\begin{array}{l}2.14 \\
(0.7)\end{array}$ & $\begin{array}{l}1.73 \\
(4.71)^{*}\end{array}$ & $\begin{array}{l}1.52 \\
(7,92)^{*}\end{array}$ & $\begin{array}{l}1.56 \\
(7.41)^{*}\end{array}$ & $\begin{array}{l}1.64 \\
(6.16)^{*}\end{array}$ & $\begin{array}{l}1.26 \\
(3.6)^{\star}\end{array}$ & $\begin{array}{l}1.54 \\
(4.32)\end{array}$ & $\begin{array}{c}1.38 \\
(11.65)^{*}\end{array}$ & $\begin{array}{l}3.52 \\
(1.18)\end{array}$ & $\begin{array}{l}2.83 \\
(2.2)^{* *}\end{array}$ & $\begin{array}{l}1.56 \\
(8.31)^{*}\end{array}$ \\
\hline "Real openness" (LNOPEN) & $\begin{array}{l}-1.37 \\
(-0.23)\end{array}$ & $\begin{array}{l}-0.53 \\
(-0.85)\end{array}$ & & & & $\begin{array}{l}0.18 \\
(0.3)\end{array}$ & $\begin{array}{l}-0.36 \\
(-0.84)\end{array}$ & & $\begin{array}{l}-3.40 \\
(-0.71)\end{array}$ & $\begin{array}{l}-1.81 \\
(-1.26)\end{array}$ & \\
\hline Integration (LCOPEN) & & & $\begin{array}{l}-0.21 \\
(-0.44)\end{array}$ & $\begin{array}{l}-0.27 \\
(-0.65)\end{array}$ & $\begin{array}{r}-0.45 \\
(-0.9)\end{array}$ & & & $\begin{array}{l}-0.32 \\
(-0.91)\end{array}$ & & & $\begin{array}{r}-0.83 \\
(-1.5)\end{array}$ \\
\hline Population (POP) & $\begin{array}{l}-0.25 \\
(-0.16)\end{array}$ & & $\begin{array}{l}0.04 \\
(0.3)\end{array}$ & $\begin{array}{l}0.00 \\
(0.02)\end{array}$ & $\begin{array}{r}-0.05 \\
(-0.4)\end{array}$ & $\begin{array}{l}0.13 \\
(1.08)\end{array}$ & & $\begin{array}{l}-0.01 \\
(-0.05)\end{array}$ & $\begin{array}{l}-0.53 \\
(-0.56)\end{array}$ & & $\begin{array}{l}-0.08 \\
(-0.59)\end{array}$ \\
\hline No. of observations & 63 & 63 & 63 & 68 & 78 & 134 & 134 & 151 & 130 & 130 & 130 \\
\hline \multicolumn{12}{|c|}{ Panel B. Two-slage least squares: Dependent variable is decadal average real per capita GDP growth } \\
\hline & (1) & $(1)^{*}$ & (2) & $(2)^{*}$ & [3] & $\{3\}^{*}$ & (4) & $(4)^{*}$ & $\{5\}$ & $\{5\}^{*}$ & \\
\hline $\begin{array}{l}\text { Average real per capita GDP } \\
\text { growth in previous decade } \\
\text { Changes over previous decede } \\
\text { in average: }\end{array}$ & $\begin{array}{l}0.64 \\
(0.88)\end{array}$ & $\begin{array}{l}1.84 \\
(0.34)\end{array}$ & $\begin{array}{l}0.89 \\
(2.34)^{\star}\end{array}$ & $\begin{array}{r}0.40 \\
(0.83)\end{array}$ & $\begin{array}{l}0.97 \\
(2.58)^{*}\end{array}$ & $\begin{array}{r}1.37 \\
(0.76)\end{array}$ & $\begin{array}{l}3.31 \\
(0.21)\end{array}$ & $\begin{array}{l}-0.52 \\
(-0.51)\end{array}$ & $\begin{array}{l}0.73 \\
(3.15)^{*}\end{array}$ & $\begin{array}{r}0.43 \\
(1.14)\end{array}$ & \\
\hline Log real openness & $\begin{array}{c}0.23 \\
(2.2)^{*}\end{array}$ & $\begin{array}{r}0.52 \\
(0.35)\end{array}$ & $\begin{array}{l}0.29 \\
(2.69)^{*}\end{array}$ & $\begin{array}{r}0.13 \\
(0.84)\end{array}$ & $\begin{array}{l}0.38 \\
(3.14)^{*}\end{array}$ & $\begin{array}{l}0.64 \\
(0.7)\end{array}$ & $\begin{array}{r}0.16 \\
(0.12)\end{array}$ & $\begin{array}{l}-0.13 \\
(-0.23)\end{array}$ & $\begin{array}{l}0.21 \\
(2.15)^{*}\end{array}$ & $\begin{array}{r}0.11 \\
(0.82)\end{array}$ & \\
\hline $\begin{array}{l}\text { Institutions } \\
\text { Contract-intensive money (CIM) }\end{array}$ & $\begin{array}{l}-0.17 \\
(-0.12)\end{array}$ & $\begin{array}{c}1.52 \\
(-0.23)\end{array}$ & & & & & & & & & \\
\hline Revolutions & & & $\begin{array}{l}0.18 \\
(0.8)\end{array}$ & $\begin{array}{r}0.13 \\
(0.7)\end{array}$ & & & & & & & \\
\hline Freedom house rating (FREEDOM & & & & & $\begin{array}{r}0.00 \\
(0.002)\end{array}$ & $\begin{array}{l}0.00 \\
(0.03)\end{array}$ & & & & & \\
\hline Rule of law (ICRG) & & & & & & & $\begin{array}{r}0.56 \\
(0.2)\end{array}$ & $\begin{array}{l}-0.73 \\
(-0.55)\end{array}$ & & & \\
\hline War deaths & & & & & & & & & $\begin{array}{r}25.20 \\
(0.54)\end{array}$ & $\begin{array}{r}19.83 \\
(0.57)\end{array}$ & \\
\hline 1980 s durnmy & & $\begin{array}{l}-0.16 \\
(-1.42)\end{array}$ & & $\begin{array}{l}-0.01 \\
(-2.92)^{2}\end{array}$ & & $\begin{array}{r}-0.02 \\
(-0.7)\end{array}$ & & & & $\begin{array}{l}-0.11 \\
(-3.09)^{*}\end{array}$ & \\
\hline 1990 s dummy & & $\begin{array}{l}0.02 \\
(0.2)\end{array}$ & & $\begin{array}{r}0.00 \\
(0.47)\end{array}$ & & & & & & $\begin{array}{c}0.00 \\
(0.5)\end{array}$ & \\
\hline 1980s Asia dummy & & $\begin{array}{l}0.00 \\
(0.01)\end{array}$ & & $\begin{array}{l}0.14 \\
(1.78)\end{array}$ & & $\begin{array}{l}0.00 \\
(0.16)\end{array}$ & & & & $\begin{array}{l}0.01 \\
(1.89)\end{array}$ & \\
\hline 1980 s Africa dummy & & $\begin{array}{l}-0.02 \\
(-0.15)\end{array}$ & & $\begin{array}{l}-0.02 \\
(-2.26)=\end{array}$ & & $\begin{array}{l}0.00 \\
(0.08)\end{array}$ & & & & $\begin{array}{l}-0.02 \\
(-1.68)\end{array}$ & \\
\hline 1880s Latin America dummy & & $\begin{array}{l}-0.01 \\
(-0.11)\end{array}$ & & $\begin{array}{l}-0.02 \\
(-3.25)^{*}\end{array}$ & & $\begin{array}{l}-0.01 \\
(-0.58)\end{array}$ & & & & $\begin{array}{l}-0.02 \\
(-3.32)^{-}\end{array}$ & \\
\hline 1990 s Asia dummy & & $\begin{array}{l}-0.02 \\
(-0.24)\end{array}$ & & $\begin{array}{l}0.00 \\
(0.3)\end{array}$ & & $\begin{array}{l}-0.01 \\
(-0.39)\end{array}$ & & $\begin{array}{l}0.03 \\
(0.97)\end{array}$ & & $\begin{array}{l}0.01 \\
(0.78)\end{array}$ & \\
\hline 1990 s Africa dummy & & $\begin{array}{l}0.03 \\
(0.2)\end{array}$ & & $\begin{array}{l}-0.01 \\
(-0.84)\end{array}$ & & $\begin{array}{r}0.02 \\
(0.39)\end{array}$ & & $\begin{array}{l}-0.04 \\
(-0.98)\end{array}$ & & $\begin{array}{l}-0.01 \\
(-0.76)\end{array}$ & \\
\hline 1990s Latin America dummy & & $\begin{array}{c}0.01 \\
(0.26)\end{array}$ & & $\begin{array}{c}0.00 \\
(0.07)\end{array}$ & & $\begin{array}{l}0.01 \\
(0.54)\end{array}$ & & $\begin{array}{l}-0.02 \\
(-0.87)\end{array}$ & & $\begin{array}{l}0.00 \\
(0.41)\end{array}$ & \\
\hline $\begin{array}{l}\text { No. of observations } \\
\text { Decades }\end{array}$ & $\begin{array}{c}193 \\
70 \mathrm{~s}, 80 \mathrm{~s} \\
\text { and } 90 \mathrm{~s}\end{array}$ & $\begin{array}{c}193 \\
70 s, 80 s \\
\text { and } 90 \mathrm{~s}\end{array}$ & $\begin{array}{r}243 \\
70 \mathrm{~s}, 80 \mathrm{~s} \\
\text { and } 90 \mathrm{~s}\end{array}$ & $\begin{array}{l}243 \\
70 \mathrm{~s}, 80 \mathrm{~s} \\
\text { and } 90 \mathrm{~s}\end{array}$ & $\begin{array}{r}189 \\
80 \text { s, } 90 \text { s }\end{array}$ & $\begin{array}{c}189 \\
80 \mathrm{~s}, 90 \mathrm{~s}\end{array}$ & $\begin{array}{r}79 \\
90 s\end{array}$ & $\begin{array}{r}79 \\
90 \mathrm{~s}\end{array}$ & $\begin{array}{l}264 \\
70 s_{1} 80 s \\
\text { and } 90 s\end{array}$ & $\begin{array}{l}264 \\
70 s, 80 s \\
\text { and } 90 s\end{array}$ & \\
\hline
\end{tabular}

Source: Authors' estimates.

Notes: Panel A relates to the level regressions in Table 1 and Panel B to the decadal growth regressions in Table 4 of DK. All variables are as defined in that paper. In Panel A, equations (1), (2), and (3) without asterisks reproduce, respectively, equations (12), (7), and (6) in Table 1. Equations with asterisks represent variations on the equations without asterisks. All regressors, except RULE, are in logarithms and are not scaled as in Tables (2)-(5) to facilitate comparison with the original equations. In Panel B, equations (1) -(5) without asterisks correspond respectively to equations (4), (6), (8), (10), and (12) in Table 4 of DK. Equations with asterisks add time and region dummies to the un-asterisked equation. T-statistics are reported under coefficient estimates. Significance at the 1 percent, 5 percent, and 10 percent levels are denoted, respectively, by “**», “**”, and “***»". 


\section{The Inappropriateness of "Real Openness"}

Technology and trade. Imagine a symmetric world populated with a large number of small endowment economies. Each economy $i$ has a fixed endowment of nontraded and traded goods, denoted by $N_{i}$ and $T_{i}$ respectively. Let each country produce a different traded good (the Armington assumption), but consume all the varieties of traded goods produced around the world. If there is a very large number of countries, each country's consumption of its own endowment of the traded good will be negligible: (almost) all of its traded good will be exported in exchange for imports of the traded goods produced elsewhere. Let $P N_{i}$ stand for the price of nontraded goods in country $i$ and let the prices of all traded goods be fixed at unity. Since the sum of exports and imports are given by $2 T_{i}$, conventionally measured openness in a country $i$ can then be expressed as $O N_{i}=2 T i /\left(P N_{i}^{*} N_{i}+T_{i}\right)$.

Preferences. Assume that preferences in each country take the Cobb-Douglas form, such that nontraded goods and traded goods (in aggregate) have fixed budget shares. Under this assumption, $2 T_{i} /\left(P N_{i}^{*} N_{i}+T_{i}\right)$ will be constant and independent of a country's endowments of $T$ and $N$. (This is because $d P N_{i} / P N_{i}=d T_{i} / T_{i}-d N_{i} / N_{i}$ ). Cross-country differences in conventionally measured openness, $O N_{i}$, will arise solely from differences in Cobb-Douglas budget shares.

Cross-national income differences. Now assume that differences in the endowment of the traded good are the only source of cross-country differences in income. That is, all countries have identical $N_{i}$ but varying $T_{i}$. Countries with larger $T_{i}$ are richer.

Cross-sectional relationship between openness and income. Under the above assumptions, there is no causal relationship that goes from trade to incomes. Cross-country differences in income are due entirely to differences in endowments. And if we run a regression of income on openness, we will get nothing. Trade shares either do not vary across countries, or they vary "randomly" with the Cobb-Douglas parameter. They have no systematic relationship to levels of income. So the econometrics will provide a good guide to the underlying reality.

The $\mathrm{AC}$ adjustment. Now suppose that we follow AC, and construct their real openness measure, $O R_{i}$. This adjustment consists of expressing the value of $i$ 's nontraded production at some benchmark country's prices, $P B$, instead of domestic prices, $P N_{i}$. The AC measure of real openness is therefore $O R_{i}=2 T_{i} /\left(P B^{*} N_{i}+T_{i}\right)$. Note that $O R_{i}$ is increasing in $T_{i}$. When we correlate $O R_{i}$ with incomes across countries, we will get a positive relationship. This is a spurious relationship, since the only source of productivity differences in this model is differences in endowments.

Remarks. In this benchmark model, the conventional measure of openness does exactly what we would like a measure of openness to do under the null hypothesis that trade does not cause productivity. The AC variant, meanwhile, imparts a positive bias to the estimated trade-income relationship. A key feature of the model above is that the elasticity of substitution in demand between $T$ and $N$ is unity. This ensures that the rise in $P N$ is just enough to keep (conventional) openness invariant to changes in the endowment (or productivity) of tradables. When the elasticity of substitution differs from one, conventional 
openness does not always deliver such a helpful result, but the bias is not unidirectional. So with an elasticity of substitution greater than one, a regression of income on conventional openness will yield (misleadingly) a positive coefficient, while with an elasticity less than one, the regression will yield (misleadingly) a negative coefficient. However, the AC real openness measure is invariant to the elasticity of substitution and hence is always positively biased. 


\section{Data and Sources}

AFRICA $=$ Dummy variable taking value 1 if a country belongs to Africa, 0 otherwise

ASIA = Dummy variable taking value 1 if a country belongs to Asia, 0 otherwise

ACCESS = Dummy variable taking value 1 for countries without access to the sea, 0 otherwise.

AREA = Land area (thousands sq. mt.) Source: Frankel and Romer (1999).

ASIAE = Dummy variable taking value 1 if a country belongs to South-East Asia, 0 otherwise.

CATH = Dummy variable taking value 1 if the country's population is predominantly catholic.

$\mathbf{C I M}=$ Contract Intensive Money. Source: World Bank (2002).

COLFR $=$ Dummy variable taking value 1 if the colonizer was France

COLUK $=$ Dummy variable taking value 1 if the colonizer was England

DISTEQ = Distance from Equator of capital city measured as abs(Latitude)/90. Source: World Bank (2002). ${ }^{23}$

ENGFRAC $=$ Fraction of the population speaking English. Source: Hall and Jones (1999).

EURFRAC = Fraction of the population speaking one of the major languages of Western Europe: English, French, German, Portuguese, or Spanish. Source: Hall and Jones (1999).

FREEDOM $=$ Political rights index. Freedom House, various issues.

FROSTAREA $=$ Proportion of land with $>5$ frost-days per month in winter. Source: Masters and McMillan (2001).

FROSTDAYS $=$ Average number of frost-days per month in winter. Source: CID Harvard University (2002) from Masters and McMillan (2001).

ICRG $=$ Rule of law index. Source: International Country Risk Guide, various issues.

${ }^{23}$ Note: World Bank (2002) refers to the data set used in Dollar and Kraay (2002), which was kindly provided by Aart Kraay. 
LAAM = Dummy variable taking value 1 if a country belongs to Latin America or the Caribbean, 0 otherwise.

LCGDP95 = Natural logarithm of per capita GDP in Purchasing-Power-Parity US dollars (PPP GDP) in 1995. Source: Penn World Tables, Mark 6.

LCOPEN = Natural logarithm of openness. Openness is given by the ratio of (nominal) imports plus exports to GDP (in nominal US dollars). Source: Penn World Tables, Mark 6. Average over all 1950-98 available data.

LFR = Dummy variable taking a value of 1 if a country has a legal system deriving from that in France.

LNOPEN = Natural logarithm of "real" openness. Real openness is given by the ratio of nominal imports plus exports to GDP in Purchasing-Power-Parity US dollars (PPP GDP). Source: Penn World Tables, Mark 5.6 and World Bank (2002).

LOGA = Labor-augmenting technological progress parameter in 1998. Source: Hall and Jones (1998)

LOGEM4 = Natural logarithm of estimated European settlers' mortality rate. Source: Acemoglu, Johnson, and Robinson (2001)

LOGFRANKROM = Natural logarithm of predicted trade shares computed following Frankel and Romer (1999) from a bilateral trade equation with "pure geography" variables. Source: Frankel and Romer (1999).

LOGFRANKROMR = Natural logarithm of predicted trade shares computed as for LOGFRANKROM except that the dependent variable in the bilateral trade (gravity) equation is nominal trade divided by nominal GDP (both in US dollars). Source: Authors' estimates.

LOGHL = Natural logarithm of human capital per worker in 1988. Source:Hall and Jones (1998).

LOGKL = Natural logarithm of physical capital per worker in 1988. Source:Hall and Jones (1998).

LOGYL $=$ Natural logarithm of GDP in Purchasing-Power-Parity US dollars (PPP GDP) per worker in 1988. Source:Hall and Jones (1998).

LSO $=$ Dummy variable taking a value of 1 if a country has a socialist legal system.

MALFAL94 = Malaria index, year 1994. Source: Gallup and Sachs (1998).

MEANTEMP = Average temperature (Celsius). Source: CID Harvard University (2002). 
MUSL = Dummy variable taking value 1 if the country's population is predominantly muslim.

OIL $=$ Dummy variable taking value 1 for a country being major oil exporter, 0 otherwise

POP $=$ Population. Source: World Bank (2002)

PROT $=$ Dummy variable taking value 1 if the country's population is predominantly protestant.

REVOLUTIONS $=$ Number of revolutions per year. Source: World Bank (2002)

RULE $=$ Rule of Law index. Refers to 2001 and approximates for 1990's institutions Source: Kaufmann, Kraay, and Zoido-Lobaton (2002)

SAFRICA $=$ Dummy variable taking value 1 if a country belongs to Sub-Saharan Africa, 0 otherwise.

SW $=$ Dummy variable taking value 0 if the country had $\mathrm{BMP}=1, \mathrm{MON}=1, \mathrm{SOC}=1, \mathrm{TAR}$ $>0.4$, or NTB $>0.4 ; 1$ otherwise. Source: Sachs and Warner (1995)

TROPICS = Percentage of tropical land area. Source: Gallup and Sachs (1998).

WARDEATHS = Fraction of population killed in wars. Source: World Bank (2002)

XCONST1970 $=$ Constraint on the executive in the 1970s. Source: Polity IV dataset. 


\section{REFERENCES}

Acemoglu, Daron, Simon Johnson, and James A. Robinson, 2001, "The Colonial Origins of Comparative Development: An Empirical Investigation," American Economic Review, Vol. 91, pp. 1369-401.

Alcalá, F., and A. Ciccone, 2002, "Trade and Productivity," Paper presented at the NBER Summer Institute (Boston, Massachusetts: National Bureau of Economic Research).

Angrist, Joshua D., and Alan B. Krueger, 1991, "Does Compulsory School Attendance Affect Schooling and Earnings?" Quarterly Journal of Economics, Vol. 106, pp. 979-1014.

Belsey, D.A., E. Kuh, and R.E. Welsch, 1980, Regression Diagnostics (New York: John Wiley and Sons).

Diamond, Jared, 1997, Guns, Germs, and Steel (New York: W.W. Norton \& Co.).

Dollar, D., and A. Kraay, 2002, "Institutions, Trade, and Growth," Carnegie-Rochester Conference Series on Public Policy, forthcoming.

Easterly, W., and R. Levine, 2002, "Tropics, Germs, and Crops: How Endowments Influence Economic Development" (Washington, D.C.: Center for Global Development and Institute for International Economics).

Engerman, Stanley L., and Kenneth L. Sokoloff, 1994, "Factor Endowments, Institutions, and Differential Paths of Growth Among New World Economies: A View from Economic Historians of the United States," NBER Working Paper No. H0066 (Cambridge, Massachusetts: National Bureau of Economic Research).

Frankel, Jeffrey, and David Romer, 1999, “Does Trade Cause Growth?” American Economic Review, Vol. 89, pp. 379-99.

Gallup, John L., and Jeffrey D. Sachs, 1998, "The Economic Burden of Malaria," Center for International Development, Harvard University.

, and Andrew D. Mellinger, 1998, "Geography and Economic Development," NBER Working Paper No. 6849 (Cambridge, Massachusetts: National Bureau of Economic Research).

Hall, Robert, and Chad I. Jones, 1998, "Why Do Some Countries Produce So Much More Output per Worker than Others?" Quarterly Journal of Economics, Vol. 114, pp. 83-116. 
Irwin, D.A., and M. Tervio, 2000, "Does Trade Raise Income? Evidence from the Twentieth Century," NBER Working Paper No. 7745 (Cambridge, Massachusetts: National Bureau of Economic Research).

Kaufmann, D., A. Kraay, and P. Zoido-Lobatón, 2002, "Governance Matters П-Upđated Indicators for 2000/01," World Bank Policy Research Department Working Paper No. 2772, Washington D.C.

Krueger, A., and A. Berg, 2002, “Trade, Growth, and Poverty," paper presented at the 2002 World Bank Annual Conference on Development Economics.

La Porta, Rafael, F. Lopez-de-Silanes, A. Shleifer, and R.W. Vishny, 1998, "The Quality of Government," Journal of Law, Economics, and Organization, Vol. 15(1), pp. 1113-55.

Masters, William A., and Margaret S. McMillan, 2001, "Climate and Scale in Economic Growth," Journal of Economic Growth, 6 (3): pp. 167-86.

Mukand, Sharun, and Dani Rodrik, 2002, "In Search of the Holy Grail: Policy Convergence, Experimentation, and Economic Performance," Harvard University.

North, Douglass C., 1990, Institutions, Institutional Change and Economic Performance, New York, Cambridge University Press.

1994, "Economic Performance Through Time," The American Economic Review, Vol. 84, No. 3, pp. 359-368.

Rodríguez, Francisco, and Dani Rodrik, 2001, "Trade Policy and Economic Growth: A Skeptic's Guide to the Cross-National Evidence," Macroeconomics Annual 2000, eds. Ben Bernanke and Kenneth S. Rogoff, MIT Press for NBER, Cambridge, MA.

Rodrik, Dani, 2000, "Comments on Frankel and Rose, 'Estimating the Effects of Currency Unions on Trade and Output'."

- 2003, "Institutions, Integration, and Geography: In Search of the Deep Determinants of Economic Growth," in Rodrik, ed., In Search of Prosperity: Analytic Country Studies on Growth, Princeton University Press, Princeton, NJ, forthcoming.

Sachs, Jeffrey D., 2001, “Tropical Underdevelopment,” NBER Working Paper No. 8119.

- and Andrew Warner, 1995, "Economic Reform and the Process of Global Integration," Brookings Papers on Economic Activity, Vol.1, pp.1-118.

Staiger, Douglas, and J.H. Stock, 1997, "Instrumental Variables Regression with Weak Instruments," Econometrica, 65:3, pp. 557-86. 